\title{
Neolithic Thessaly: radiocarbon dated periods and phases
}

\author{
Agathe Reingruber ', Giorgos Toufexis ${ }^{2}$, Nina Kyparissi-Apostolika 3, Michalis Anetakis 4, \\ Yannis Maniatis 5 and Yorgos Facorellis 6 \\ 1 Institute of Prehistoric Archaeology, Free University of Berlin, Berlin, DE \\ agathe.reingruber@fu-berlin.de \\ 2 Ephorate of Antiquities of Larissa, Larissa, GR \\ geotoufexis@yahoo.gr \\ 3 Emerita Directress of the Ephorate of Palaeoanthropology and Speleology, Athens, GR \\ nkyparissi@hotmail.com \\ 4 Ephorate of Antiquities of Magnesia, Volos, GR \\ 5 Emeritus Director, Laboratory of Archaeometry, Institute of Nanoscience and Nanotechnology, National Centre \\ for Scientific Research "Demokritos", Athens, GR \\ y.maniatis@inn.demokritos.gr \\ 6 Department of Antiquities and Works of Art Conservation, Faculty of Fine Arts, Athens University of Applied \\ Sciences, Athens, GR \\ yfacorel@teiath.gr
}

\begin{abstract}
Thessaly in Central Greece is famous for settlement mounds (magoules) that were already partly formed in the Early Neolithic period. Some of these long-lived sites grew to many metres in height during the subsequent Middle, Late and Final Neolithic periods, and were also inhabited in the Bronze Age. Such magoules served as the backbone for defining relative chronological schemes. However, their absolute dating is still a topic of debate: due to a lack of well-defined sequences, different chronological schemes have been proposed. New radiocarbon dates obtained in the last few years allow a better understanding of the duration not only of the main Neolithic periods, but also of the different phases and sub-phases.
\end{abstract}

KEY WORDS - Thessaly; Neolithic; radiocarbon dates; absolute and relative chronology

\section{Neolitska Tesalija: \\ Radiokarbonsko datirana obdobja in faze}

IZVLEČEK - Pokrajina Tesalija v osrednji Grčiji ima ohranjene številne naselbinske gomile (magoules), ki so nastale že v obdobju zgodnjega neolitika. Nekatera od teh dolgoživih najdǐ̌č so merila tudi več metrov v višino v kasnejših neolitskih obdobjih ( $v$ srednjem, poznem in finalnem neolitiku), poseljena pa so bila še tudi v času bronaste dobe. Te naselbine so predstavljale osnovo pri definiranju relativnih kronoloških shem. Zaradi pomanjkanja dobro definiranih stratigrafskih sekvenc pa ostajajo njihove absolutne datacije predmet številnih razprav in različnih kronoloških shem. V preteklih letih smo pridobili številne nove radiokarbonske datume, ki nam nudijo boljši vpogled v trajanje tako neolitskega obdobja v celoti kot tudi vpogled v časovno razdelitev posameznih neolitskih faz in podfaz $v$ Tesaliji.

KLJUČNE BESEDE - Tesalija; neolitik; radiokarbonski datumi; absolutna in relativna kronologija 
Introduction: early investigations and the first radiocarbon dates

The first scientific investigations of Neolithic sites in Thessaly were conducted in its south-eastern areas, close to the Pagasitic Gulf (the Regional Unit of Magnesia - compare Figure 1). Situated in the hilly areas west of the modern city of Volos and close to the village of Sesklo, the prehistoric eponymous magoula was investigated more than a century ago by Christos Tsountas, in 1901-1902 (Tsountas 1908). The excavations revealed a lengthy stratigraphic succession covering all periods of the Neolithic, although in today's perception the earlier periods at the site are more prominent. Simultaneously, the nearby site of Dimini became famous for the later and final periods of the Neolithic. These findings gave rise to international as well as Greek interest in Thessalian magoules (e.g., Arvanitopoulos 1910); British archaeologists (Wace, Thompson 1912) recorded and occasionally investigated some Thessalian magoules.

With comprehensive publications by French (Béquignon 1932.89-191) and German (Grundmann 1932. 102-123) researchers in the 1930s, international interest in Neolithic Thessaly intensified. In 1941, excavations based on a extorted permit were carried out in Visviki Magoula by Hans Reinerth and his team from the universities of Berlin and Tübingen (Alram-Stern, Dousougli-Zachos 2015). Thanks in part to the intervention of the German Archaeologi- cal Institute in Athens, the work permit was not renewed in 1942 (Hauptmann 2015.2). More than a decade later, the prolific German-Greek collaboration between Vladimir Milojčić and Dimitrios R. Theocharis led to the systematic investigation of magoules situated mainly in eastern and southern Thessaly. The excavation methods applied by Milojčić met the highest standards of their time. The interpretation of the finds and their contexts relied largely on his highly erudite chronological scheme, which was based on a relative chronological approach supported by, and developed from, the method of comparative stratigraphy. According to this method, all relevant stratigraphic sequences from north-eastern Africa, the Near East and Southeast Europe were compared and tied together in a supraregional, not to say intercontinental perspective. The expectations of the Neolithic in Greece were thus not unbiased, since Milojcicic's interpretations of both the beginning and end of the period were largely influenced by his view from the North (the Balkans with the Starčevo and Vinča cultures - (Milojčić 1950/51.54-63) and from the East (the Near East with the PPN - Milojčic 1956).

Milojčićs relative chronological appraisals were challenged in the late 1950s by the new and indeed revolutionary radiocarbon dates. Due to his premature death in 1978, Milojčić did not have the chance to re-appraise his views. In his last critical article on this topic (Milojčić 1973.3-11), he points to the contradictions not only between relative and absolute chro-

Fig. 1. Thessaly: the vast plain (approx. $14000 \mathrm{~km}^{2}$ ) surrounded by steep mountains is divided by the MidThessalian Hills (Revenia) into eastern and western parts; Magnesia with the islands of the Northern Sporades and the zone around the Pagasitic Gulf is also part of Thessaly (included in the study area is the municipality of Domokos in the northern Phthiotis). Only radiocarbon dated sites from the Neolithic are plotted (c. 6500-3300 cal BC): rendered in black are the 10 sites that were radiocarbon dated between the 1960s and 1990s; recently dated 13 sites are in red. Filled-in

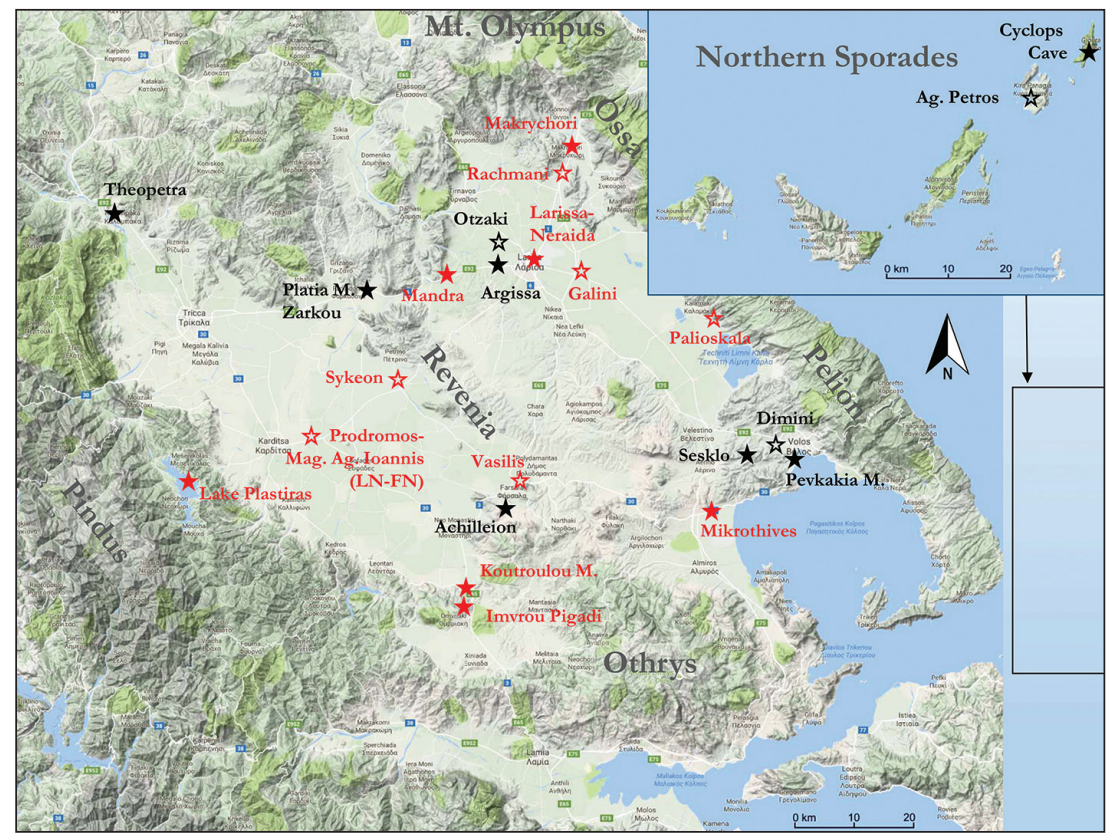
stars: sequences with four or more dates per site and phase; empty stars: 1-3 dates per site and phase (background for the map from URL: https://www.google.de/maps). 
nology, but also to the discrepancy between astronomical and radiocarbon years. And indeed, the first internationally accepted calibration curve was achieved only in late 1985 (Stuiver, Becker 1986). His repeated cautioning of an unduly uncritical acceptance of the radiocarbon method might have derived even from the dates obtained on animal bones he himself had excavated in Argissa Magoula in 1958: Reiner Protsch and Rainer Berger (1973.235-239) published three highly doubtful dates on bones that led to the assumption that the Early Neolithic (henceforth, EN) started in Thessaly around $7000 \mathrm{BC}$ (for a critique of these dates, compare Reingruber 2015; Reingruber, Thissen 2016. www.14sea.org/3_IIc. html\#).

Milojčićs critique of the radiocarbon method had a lasting impact on investigations carried out by German-speaking archaeologists in Southeast Europe. Quite to the contrary, investigations by English-speaking archaeologists (e.g., Marija Gimbutas in Achilleion and Colin Renfrew in Sitagroi: Gimbutas 1974. 283, Tab. 2; Renfrew 1970.280-311) used the method in their research, with well-known results. Also, Theocharis recognised the radiocarbon method as a

\begin{tabular}{|c|c|}
\hline & THESSALY \\
\hline \multirow{2}{*}{6750 в.с.. } & $\ldots \ldots \ldots \ldots$ \\
\hline & Aceramic Neolithic \\
\hline 6400 в.С. . & Frühkeramikum \\
\hline \multirow{2}{*}{ Early Neolithic } & Protosesklo \\
\hline & Vorsesklo \\
\hline 5700 . & $\begin{array}{r}\cdots \cdots \\
: I\end{array}$ \\
\hline Middle Neolithic & Sesklo : II \\
\hline \multirow[t]{2}{*}{5300 . } & \\
\hline & $\begin{array}{l}\text { Dimini I-Tsangli-Larissa } \\
\text { Dimini II-Arapi }\end{array}$ \\
\hline \multirow[t]{2}{*}{ Late Neolithic I } & $\begin{array}{l}\text { Dimini III-Otzaki A, B } \\
\text { (Ayia Sophia phase?) }\end{array}$ \\
\hline & $\begin{array}{c}\text { Dimini IV-Otzaki C } \\
\ldots \ldots \ldots \ldots \ldots\end{array}$ \\
\hline $4300 \ldots$. & : Early \\
\hline \multirow[t]{2}{*}{ Late Neolithic II } & Rachmani : Middle \\
\hline & $3700-$ \\
\hline \multirow[t]{2}{*}{3500} & $?$ \\
\hline & \\
\hline 3100 & $?$ \\
\hline $\begin{array}{l}2900 \\
\text { Early Bronze Age }\end{array}$ & \\
\hline
\end{tabular}

Fig. 2. Duration of Neolithic periods and their phases as proposed by John Coleman in 1992. powerful tool early on, and compiled the available radiocarbon dates not only from Thessaly, but from all over Greece (Theocharis 1973.119). He was followed in this approach by younger scholars, e.g., an updated version of his list inclusive of dates from Anatolia was published by Mies H. J. M. N. Wijnen (1981.130-133). However, it was not until the end of the $20^{\text {th }}$ century that these dates were analysed in a broader context.

\section{First radiocarbon-based appraisals of the du- ration of Neolithic periods and phases}

The first thorough synthesis based on absolute chronology was developed by John Coleman (Coleman 1992.206, Fig. 4). Not only did he bring together both published and hitherto unpublished dates from Greece, he also made them easily comparable by systematically using the calibrated dates, not uncalibrated values. He presented the dates separately for each region and compared the periods and phases obtained by relative chronological assessments accordingly. In this way, the duration of each period and phase became more evident (Fig. 2).

According to the knowledge of that time, the Neolithic period started in Thessaly with a Preceramic (Aceramic) phase comparable to the Pre-Pottery Neolithic in the Near East. Its beginning was almost undisputedly accepted as $7000 \mathrm{BC}$, being thus coeval with the PPNB in Anatolia. Together with the EN, it should have lasted until $5700 \mathrm{BC}$. In contrast, the subsequent period of the Middle Neolithic (henceforth, MN) encompassed only a few centuries, from 5700 to $5300 \mathrm{BC}$. It was followed by the, again, millennium-long phases of the Late Neolithic (henceforth, LN), the LN I ('Dimini': 5300-4300 BC) and LN II ('Rachmani': 4300-3000 BC).

As hardly any dates from Thessaly were available, not even from sites with long stratigraphic sequences, Coleman interpolated the duration of the Thessalian phases by using the results from neighbouring regions, both northern (from Macedonia) and southern (from the Argolid). For example, the dates available for the MN in Serbia started only after 5800 BC (Coleman 1992.209-210). The dates from the cave of Franchthi in the Argolid also point to such a late EN-MN transition. Nonetheless, for the earlier periods (EN and $\mathrm{MN}$ ) the sequence of dates from Achilleion (Gimbutas 1989.Fig. 3.4 and Fig. 3) could have served as a reliable background. However, Coleman decided in favour of a supra-regional balance between stratigraphic sequences, still very much in the tradition of relative chronological appraisals. 


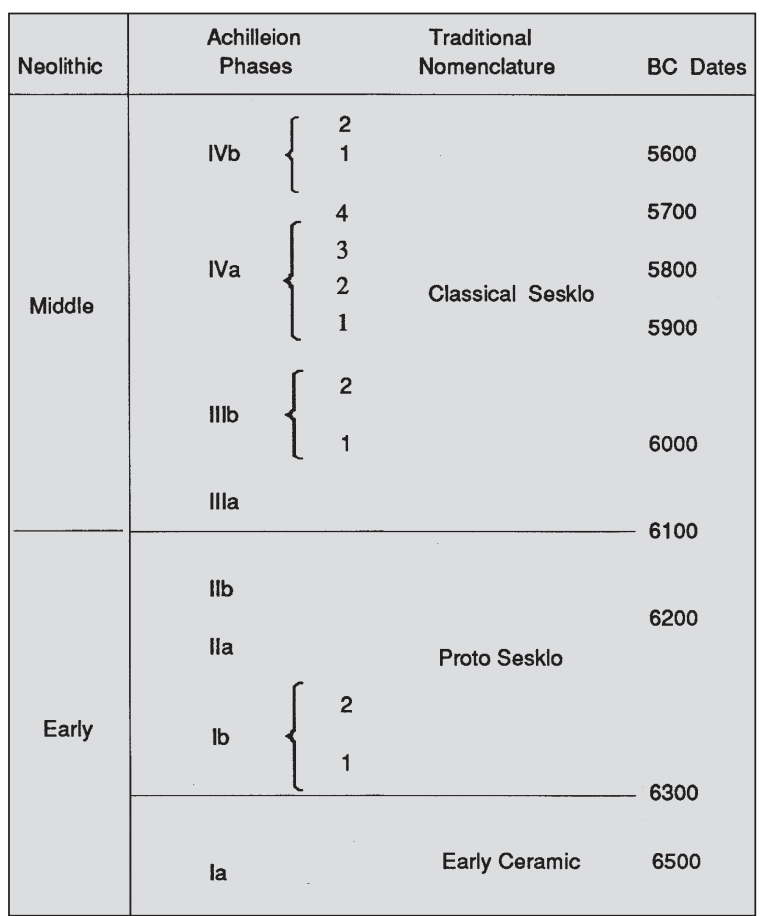

Fig. 3 Duration of the Early and Middle Neolithic periods and their phases as proposed by Maria Gimbutas in 1989.

Moreover, he did not verify the quality of these dates (especially not the dates obtained on bones from Argissa Magoula). At that time, it was impossible to determine which dates were more reliable and which were outliers. This is especially the case with the later Neolithic periods, which provided almost no direct evidence, the duration of these phases being more or less guesswork.

Nevertheless, Coleman's scheme became very influential and was often quoted in subsequent studies, in catalogues, handbooks and overviews (e.g., $\mathrm{Pa}$ pathanasopoulos 1996.28-29, Fig. 3; Alram-Stern 1996.100, Fig. 4; Andreou et al. 1996.538, Tab. 1). The duration of the EN and MN periods as well as the transition between the periods around 5800/ $5700 \mathrm{BC}$ became largely accepted. For the Late Neolithic a competing terminology also came into use: Coleman's LN I there is divided into an LN I and an LN II; Coleman's LN II is labelled as Final Neolithic or Chalcolithic (Tsirtsoni 2016.19, Tab. 1 and Fig. 4). In order to avoid confusion resulting from the use of the terms 'Late Neolithic II', 'Final Neolithic' or 'Chalcolithic', we follow here the terminology proposed by Hans-Joachim Weißhaar (1989) and Zoï Tsirtsoni (2016), where 'Final Neolithic' (henceforth, FN) is synonymous with 'Chalcolithic' (henceforth, $\mathrm{FN} / \mathrm{Ch}$ ) and is dated to the second half of the $5^{\text {th }}$ and to the $4^{\text {th }}$ millennium BC. The labels LN I and LN II

\begin{tabular}{|c|c|c|c|}
\hline $\begin{array}{l}\text { Date } \\
B C\end{array}$ & $\begin{array}{l}\text { Periodization } \\
\text { (dominant } \\
\text { Aegean } \\
\text { terminology) }\end{array}$ & $\begin{array}{l}\text { Periodization } \\
\text { (alternative } \\
\text { Aegean } \\
\text { terminology) }\end{array}$ & Thessaly \\
\hline 5400 & \multirow{2}{*}{$\begin{array}{c}\text { Late Neolithic } \\
\text { I }\end{array}$} & \multirow{2}{*}{ LN Ia } & \multirow{2}{*}{$\begin{array}{c}\text { Tsangli- } \\
\text { Larissa } \\
\text { Arapi }\end{array}$} \\
\hline 5200 & & & \\
\hline 4800 & $\begin{array}{c}\text { Late Neolithic } \\
\text { II }\end{array}$ & LN Ib & $\begin{array}{l}\text { Otzaki } \\
\text { Dimini }\end{array}$ \\
\hline 4500 & \multirow{3}{*}{$\begin{array}{c}\text { (Final } \\
\text { Neolithic or } \\
\text { Chalcolithic) }\end{array}$} & \multirow{2}{*}{ LN IIa } & \multirow[b]{3}{*}{$\begin{array}{c}\text { Petromagoula } \\
\text { Mikrothives }\end{array}$} \\
\hline 4000 & & & \\
\hline 3700 & & LN IIb & \\
\hline 3300 & $\begin{array}{c}\text { Early Bronze } \\
\text { Age I }\end{array}$ & EBA I & Pefkakia 1-2 \\
\hline 2800 & $\begin{array}{c}\text { Early Bronze } \\
\text { Age II }\end{array}$ & EBA II & Pefkakia 3 \\
\hline
\end{tabular}

Fig. 4. Duration of the Late and Final Neolithic (Chalcolithic) periods and their phases as proposed by Zoi Tsirtsoni in 2016.

are used exclusively for the millennium between 5500 and $4500 \mathrm{cal} \mathrm{BC}$.

At the beginning of our century, it became even more evident that the scarcity of dates left serious doubts as to how exactly to define the length of a certain period. Catherine Perlès questioned the long duration of the EN, but in her general appraisal she reverted to the scheme as proposed by Coleman (Perlès 2001. 92, 99). Especially in a circum-Aegean perspective, a re-evaluation of the old dates has led to other possible interpretations (Reingruber, Thissen 2005; 2009; Reingruber 2008). New dates support these adjustments and substantiate new appraisals.

\section{New evidence and new appraisals}

With every decade, more dates become available, and especially in the last few years, sound sets of dates allow for some rectifications. Certainly, these 
Fig. 5. Sites with radiocarbon dates for the different periods and phases of the Neolithic Age (c. 6500-3300 cal BC). Filled-in stars: sequences with four or more dates per site and phase; empty stars: 1-3 dates per site and phase (background for the map from URL: https://www. google.de/maps).

new appraisals must also be considered as provisional: each new sequence will provide new insights. However, future adjustments will probably not be necessary so much in terms of centuries, but rather in terms of decades.

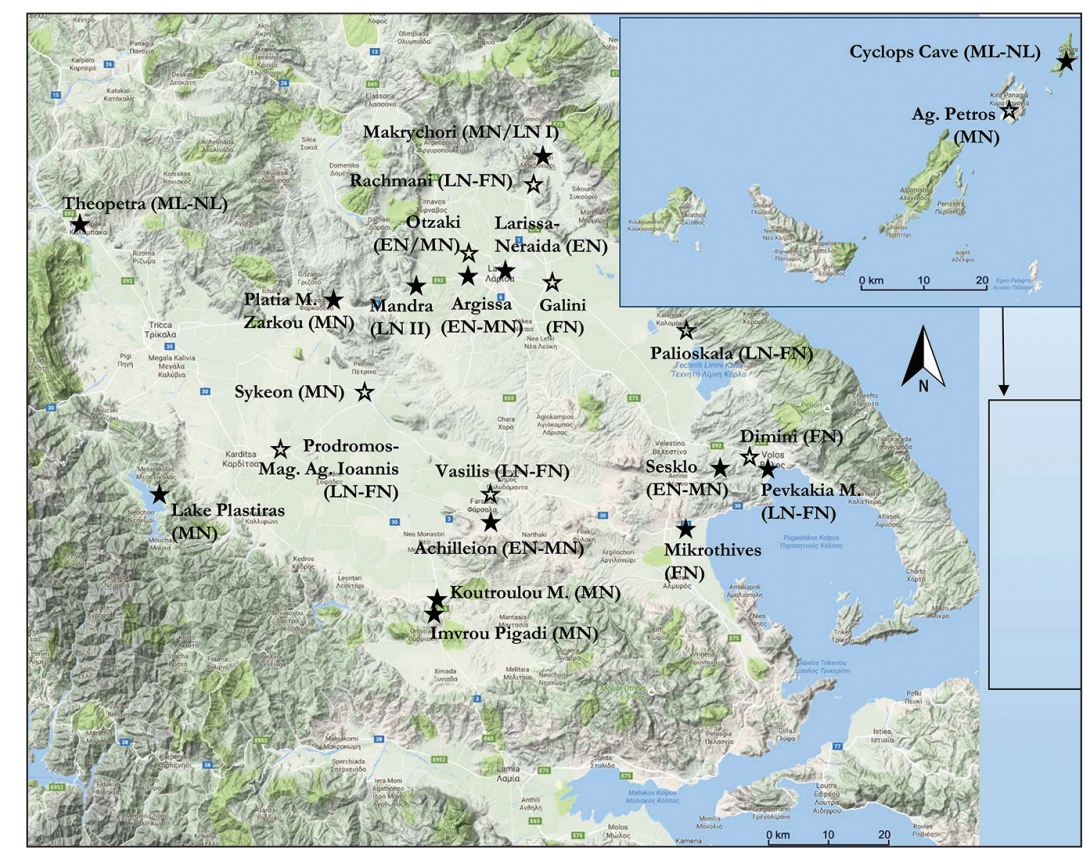

This evaluation relies on the dates from two caves with sequences from both the Mesolithic (henceforth, ML) and the Neolithic (Theopetra Cave and Cyclops Cave) and from 21 open-air Neolithic settlements. Of these, 13 sites have only recently been dated (since 2014 - compare Fig. 1). Many of the new dates derive from early MN sites, especially from sites located in western Thessaly, as well as from sites of the $\mathrm{LN}$ and $\mathrm{FN} / \mathrm{Ch}$ located in particular in eastern Thessaly (Fig. 5).

The end of the Mesolithic and beginning of the Neolithic in Thessaly (c. 6600/6500 cal BC)

The Mesolithic is underrepresented in Thessaly. As is the case in other regions as well, it is very difficult to trace the ephemeral remains of highly mobile groups of people, except in caves where they have been protected from both erosion and alluvial or colluvial coverage. That Mesolithic populations indeed used the terrestrial and marine resources in the region of Thessaly is demonstrated by the two caves situated in its far west (Theopetra: compare Kyparissi-Apostolika 2000a; 2000b; Facorellis et al. 2001) and far east (Cyclops Cave on the island of Youra: compare Sampson et al. 2003; Facorellis et al. 1998).

In the cave near the modern village of Theopetra, a body of 20 radiocarbon dates shows that the Mesolithic ended there around $6680 \mathrm{cal} \mathrm{BC}$ (Tab. 1). Two further dates on charcoal fit into the sequence of the EN, although the first phase is probably not represented. The final publication of the site will certain- ly allow more detailed interpretations (KyparissiApostolika et al. forthcoming).

The complicated stratigraphy of the Cyclops Cave is also reflected in the radiocarbon dates, with either many outliers or with samples taken from mixed contexts. The many dates run on shells that needed MRE-corrections (compare Table 2) present another impediment.

Judging by the dates from the two caves, the ML-EN transition must have occurred anywhere between 6680 and $6400 \mathrm{cal} \mathrm{BC}$. In the late 1950s, the transition between the Mesolithic (Epipalaeolithic in Near Eastern terminology) and the Pottery Neolithic was

\begin{tabular}{|lll|}
\hline \multicolumn{3}{|c|}{ Theopetra Cave } \\
\hline Periods and Phases & cal BC $1 \sigma$ & Material \\
\hline Lower Mesolithic & $8780-7530$ & charcoal \\
\hline Upper Mesolithic & $7450-6680$ & $\begin{array}{l}\text { charcoal and } \\
\text { human bones }\end{array}$ \\
\hline Early Neolithic & $6400-6230$ & charcoal \\
\hline Middle Neolithic & $5990-5470$ & charcoal \\
\hline Late Neolithic I & $5490-5070$ & charcoal \\
\hline Late Neolithic II & $4970-4850$ & charcoal \\
\hline $\begin{array}{l}\text { Final Neolithic/ } \\
\text { Chalcolithic }\end{array}$ & $4460-4230$ & charcoal \\
\hline
\end{tabular}

Tab. 1. Theopetra Cave: three dates with huge standard deviations (>125 years BP) are not included in this table (compare Reingruber, Thissen 2016). All dates have been calibrated along the IntCal13 calibration curve (Reimer et al. 2013), using the OxCal v4.2.4 program throughout this contribution (Bronk Ramsey 2009). 


\begin{tabular}{|c|c|c|}
\hline \multicolumn{3}{|c|}{ Cyclops Cave } \\
\hline Periods and Phases & cal BC $1 \sigma$ & Material \\
\hline Lower Mesolithic & $8600-8350$ & charcoal \\
\hline Upper Mesolithic & $8300-6420$ & shells (MRE-corrected) and charcoal \\
\hline Early Neolithic & $6450-6030$ & shells (MRE-corrected) and charcoal \\
\hline Middle Neolithic & $6070-5670$ & bone and charcoal \\
\hline Late Neolithic I & $5300-5000$ & shells (MRE-corrected) \\
\hline Neolithic? & $4230-4050$ & charcoal \\
\hline $\begin{array}{l}\text { Final Neolithic/ } \\
\text { Chalcolithic }\end{array}$ & $3650-3530$ & charcoal \\
\hline
\end{tabular}

Tab. 2. Cyclops Cave: the dates on shells are corrected by the Marine Reservoir Effect (MRE), using the $\Delta R=167 \pm 11614 \mathrm{C} \mathrm{yr}$ in conjunction with the Marine13 calibration curve (compare Facorellis, Vardala-Theodorou 2015; Facorellis et al. 1998).

described as a distinguishable period in human prehistory and labelled the 'Pre-Pottery Neolithic' (PPN) or 'Preceramic Period' (Milojčić 1956; Theocharis 1973). Radiocarbon dates from the 1960s seemingly confirmed this interpretation, since $c .7000 \mathrm{BC}$ for the 'Preceramic Period' in the Aegean overlaps with the final phase of the PPNB in Anatolia. As has been shown elsewhere (Reingruber, Thissen 2009), these early dates are highly dubious. For example, the dates obtained on bones from Argissa Magoula have to be excluded from all future evaluations: they were run on bones before the introduction of the AMS-method; they were published in such a way that the date and the bone sample from which it derived cannot be matched (Protsch, Berger 1973) and, in the worst case, they might have been faked (Reingruber, Thissen 2016: www.14sea.org/3_IIc.

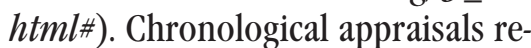
lying on the bone samples from Argissa Magoula must therefore be rejected. Moreover, the levels presented as 'Preceramic' contained considerable amounts of sherds that were interpreted by their excavators as intrusions from above (Reingruber 2008).

The radiocarbon dates for the EN I levels at the magoules of Argissa and Sesklo fit well with the gaps

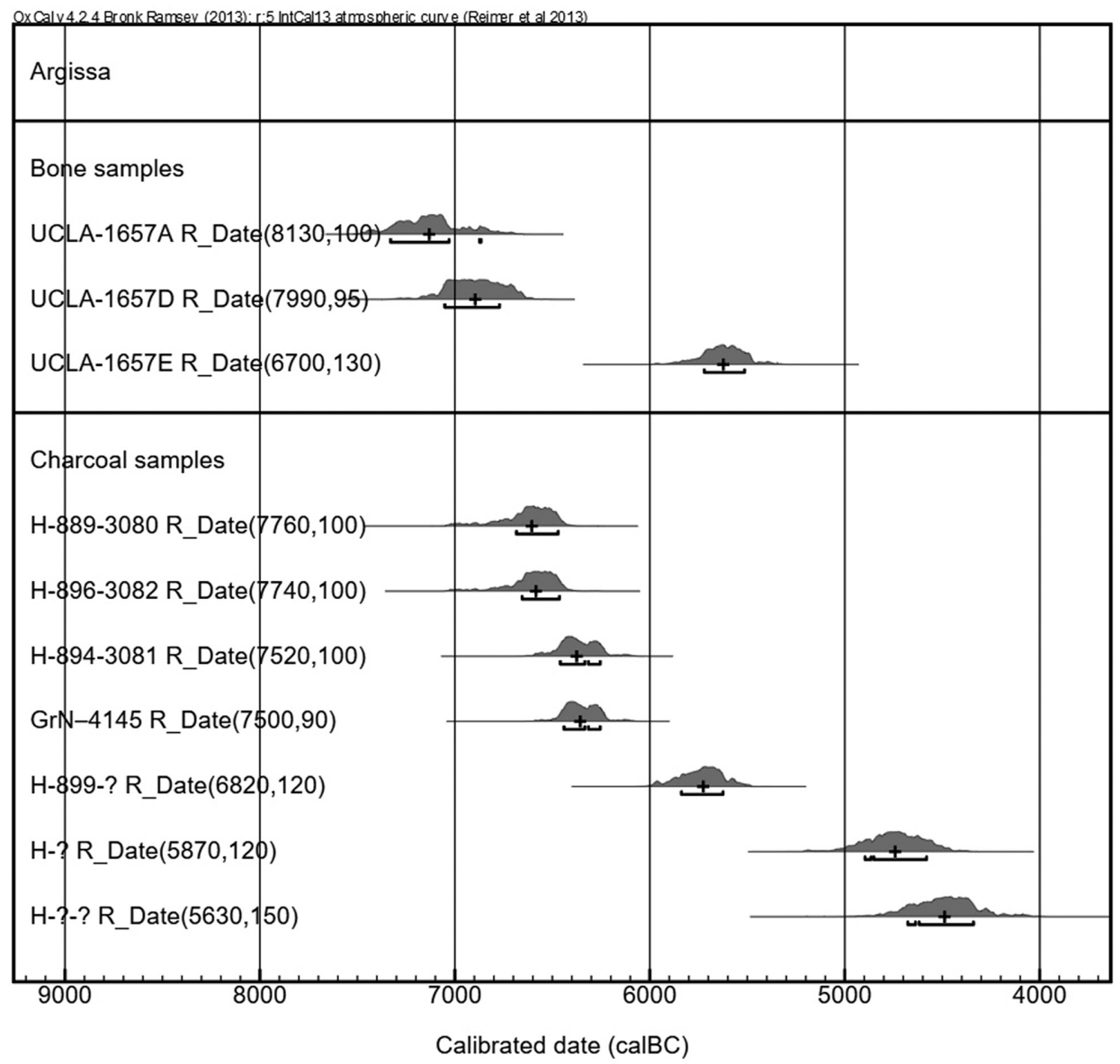

Fig. 6. Argissa Magoula: note that the bone samples published in 1973 are erroneous and that the reliable sequence starts with the charcoal samples, for which 6600 cal BC serves as a terminus post quem (Reingruber 2008.157). 


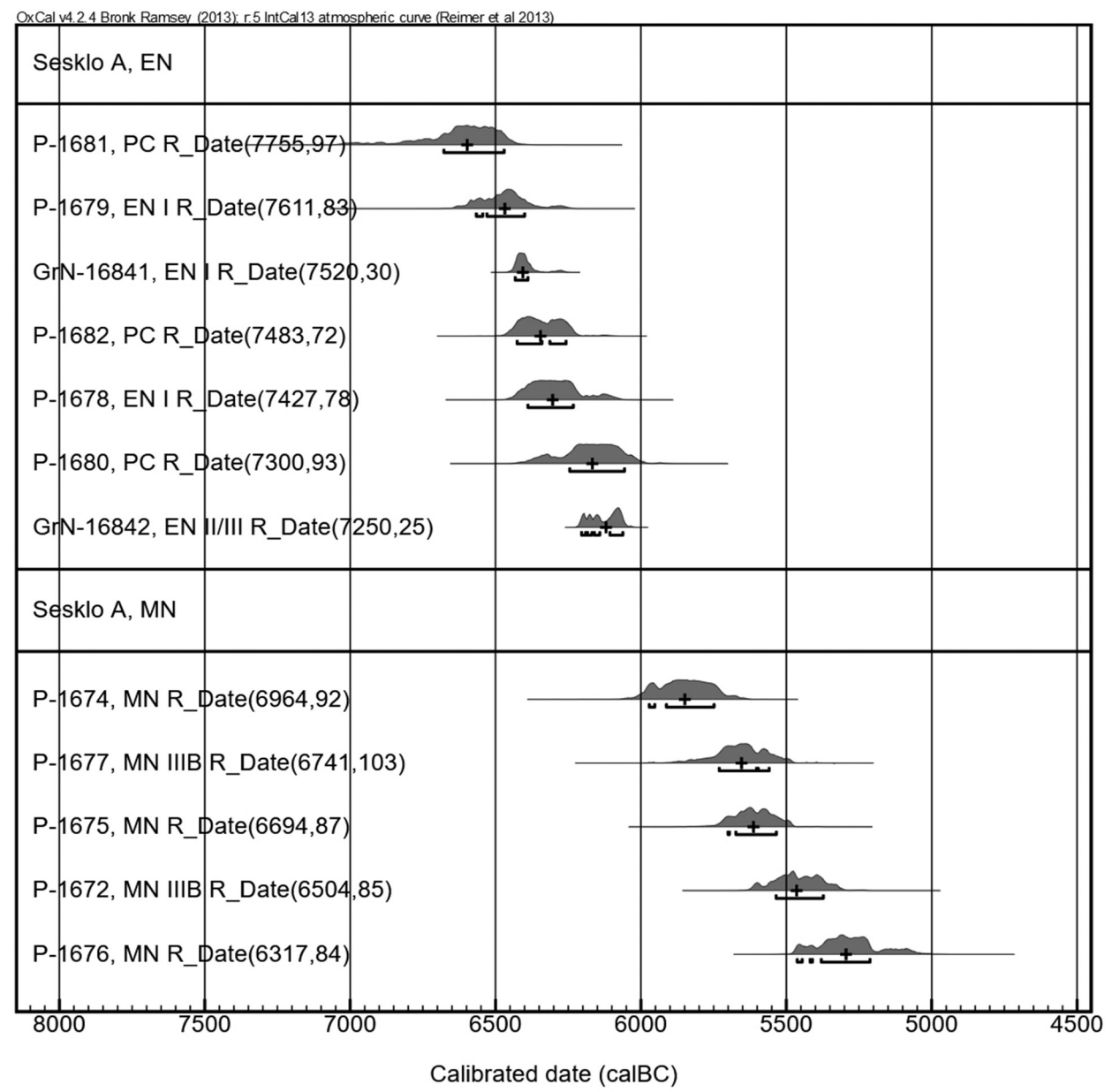

Fig. 7. Sesklo Magoula (or Sesklo A): all dates are on charcoal (Lawn 1975).

in the sequences of the caves mentioned above (Figs. 6 and 7). In a circum-Aegean perspective, this interpretation coincides well with the newly obtained dates from Ulucak, Çukuriçi Höyük, Franchthi and Paliambela-Kolindros (dates and references are compiled in Reingruber, Thissen 2016). Some of the earliest sites dated to around $6650 \mathrm{cal} \mathrm{BC}$ may have at their base a thin 'Aceramic' level, but they are exceptions rather than the rule. It could be further argued that the Thessalian dates are some decades younger: If it is accepted that the four oldest charcoal samples from Argissa Magoula (three from so-called pits and one from level $28 \mathrm{~b}$ above them) do indeed belong to the same phase of the EN I (compare Reingruber 2008.Tab. 3.1), then their combined result post-dates 6500 cal BC (Fig. 8). Even this result must be regarded as a terminus post quem (TPQ), since the charcoal derived from unknown wood species: the oldwood effect can thus not be excluded (compare Reingruber, Thissen 2009; 2016). Therefore, a re-evaluation of the old dates from Argissa and Sesklo shows that the beginning of the EN in Thessaly can be dated

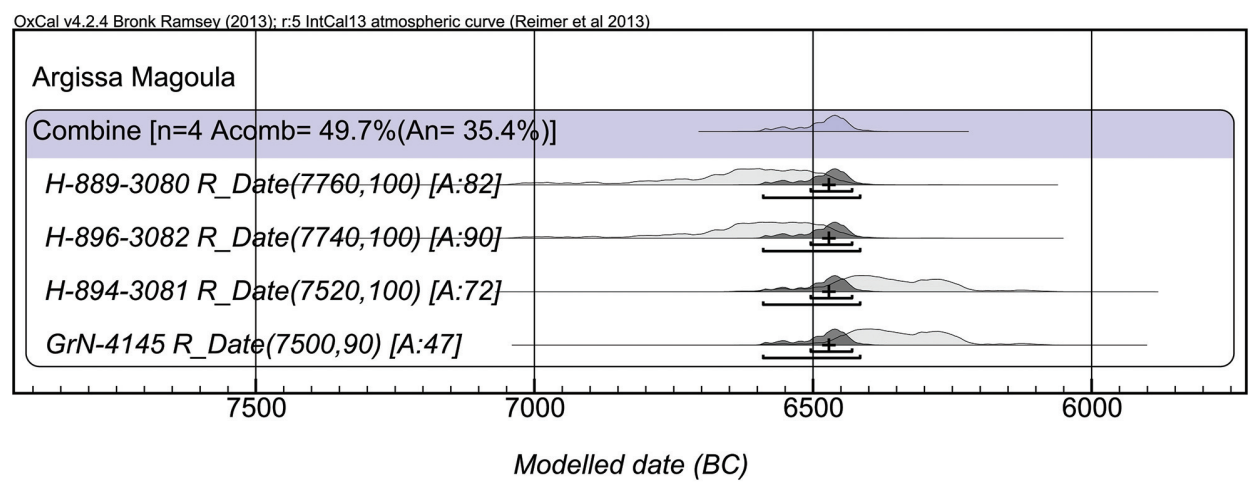

Fig. 8. Argissa Magoula and the beginning of the Neolithic as resulting from combining the charcoal dates. 


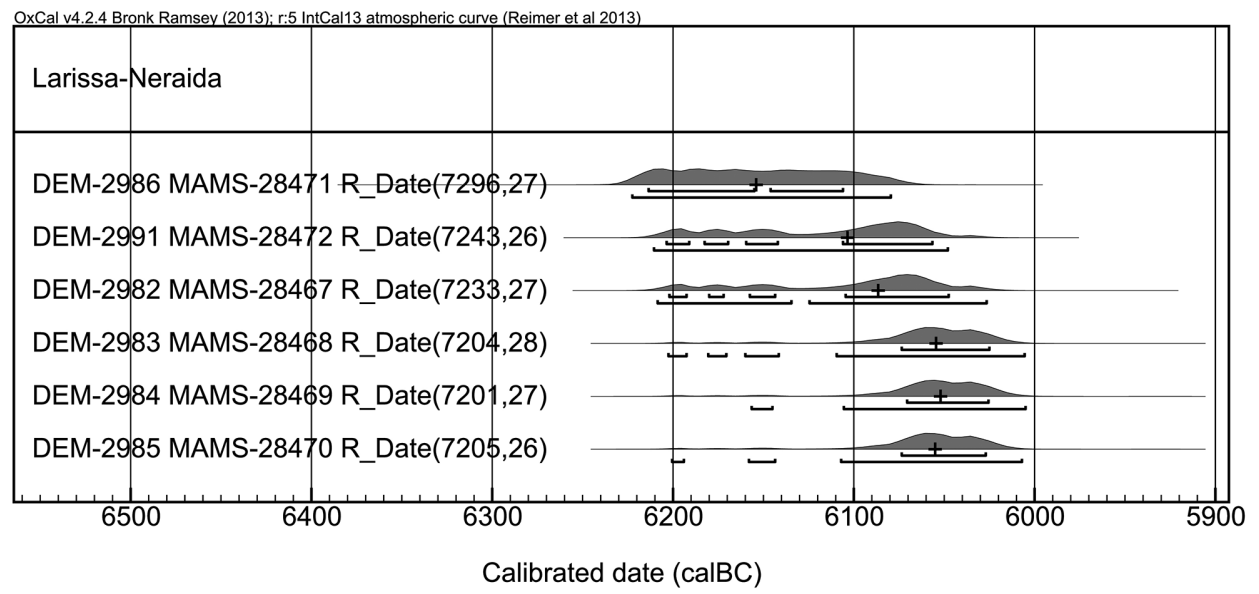

Fig. 9. Dates for the Early Neolithic II from Larissa-Neraida.

to only after $6500 \mathrm{cal} \mathrm{BC}$. In addition, new dates from Sesklo run on old samples support this view: the oldest of them (DEM-2440) resulted in $6450 \mathrm{cal} \mathrm{BC}$ (Maniatis, Kotsakis 2016).

Although Thessaly is especially famous for the EN period, unexpectedly, despite the many efforts of the last decades, evidence for the beginning of the Neolithic Age is difficult to obtain. However, pottery of the 'Protosesklo'-type was discovered (Anetakis 2012) during rescue excavations in the low magoula of Neraida in the city of Larissa. Six ${ }^{14} \mathrm{C}$ dates date this phase of the EN (EN II or 'Protosesklo') between c. 6200 and 6000 cal BC (Fig. 9) - but note the long interval covered by three of the dates. Such intervals are the result of flat portions (plateaus) in the calibration curve (see below). The median values, even of date DEM-2986 with 6150 cal BC, especially of all other dates at $6100 / 6080 \mathrm{cal} \mathrm{BC}$, are compatible with the end of the EN II.

The most comprehensive sequence is still the one from Achilleion, including 40 dates from well-defined excavation units. Two more dates with huge standard deviations derive from a test-pit and have not been included in the statistical model proposed in Fig. 10. The model confirms the beginning of Phase I in Achilleion shortly after $6300 \mathrm{cal} \mathrm{BC}$, and the transition from the EN to the MN during Phase IIIb around $6000 \mathrm{cal} \mathrm{BC}$ (note that no dates are available for Phase IIIa).
The stratigraphic sequence ends in Phase IVa, with layers 2-10 dating to the $60^{\text {th }}$ century cal $\mathrm{BC}$. Additional samples assigned to Phase IVa derive from pits and ditches dug into layers 10-21. They suggest that the occupation lasted until $5800 \mathrm{cal} \mathrm{BC}$. The single, much later, date for Phase IVb also derives from a pit that attests a brief re-occupation around 5540 cal BC. This youngest date corresponds well with the end of the MN at $5500 \mathrm{cal} \mathrm{BC}$.

Achilleion Phase Ia starts according to this model at $6280 \mathrm{cal} \mathrm{BC}$ and thus does not date to the beginning of the EN in Thessaly, but is coeval with the EN II phase. This view is also supported by the pottery with painted motifs of the 'Protosesklo' variant appearing from Phase I onwards. Furthermore, 6280 cal BC can be considered a useful terminus ante quem (TAQ) for the EN I ending around $6300 \mathrm{cal} \mathrm{BC}$. Finally, if Coleman had given more weight to this sequence of dates, an alternative view regarding the transition EN/MN could have been considered: there is no direct evidence from Thessaly that the EN lasted there until $5800 \mathrm{cal} \mathrm{BC}$ (compare Tab. 3).

\begin{tabular}{|lll|}
\hline $\begin{array}{l}\text { Abs. dates } \\
\text { cal BC } 1 \sigma\end{array}$ & Archaeological phases & Sites \\
\hline c. 6600 & EN I ('Initial Neolithic') & $\begin{array}{l}\text { Beginning of the EN in predominantly coa- } \\
\text { stal and/or hilly areas of the circum-Aegean }\end{array}$ \\
\hline c. $6500-6300$ & EN I ('Early Ceramic') & Argissa, Sesklo \\
\hline $6280-6070$ & EN II ('Protosesklo') & Achilleion I-II, Sesklo, Larissa-Neraida \\
\hline $6070-5980$ & EN III/MN I ('Presesklo') & Achilleion IIIb, Otzaki \\
\hline $5980-5800$ & MN I ('Sesklo I') & Achilleion IVa, Cyclops Cave, Theopetra \\
\hline c. $5750-5600$ & MN II ('Sesklo II') & Argissa, Sesklo, Agios Petros, Theopetra \\
\hline c. 5540 & MN III ('Sesklo III') & Achilleion IVb, Sesklo \\
\hline
\end{tabular}

Tab. 3. The Early and Middle Neolithic sequences in Thessaly with the two terminological proposals at the transition EN-MN (in red). In brackets, the terms used and/or established by Milojčić and Theocharis. 


\section{The EN-MN transition $(6000 / 5900$ cal BC)}

In the terminology of Milojčić, the final phase of the EN received the label 'Vorsesklo' ('Presesklo') and is relative-chronologically situated between 'Protosesklo' (EN II) and 'Sesklo' (MN). Expanding on this phase, Johanna Milojčić-von Zumbusch labelled it 'Magulitsa culture' and on the basis of pottery styles from Otzaki Magoula advocated two sub-phases ( $M i$ lojčić-v.Zumbusch 1971.146-148): the older phase of the middle strata with so-called 'Barbotine' pottery with finger pinches and nail impressions, and the

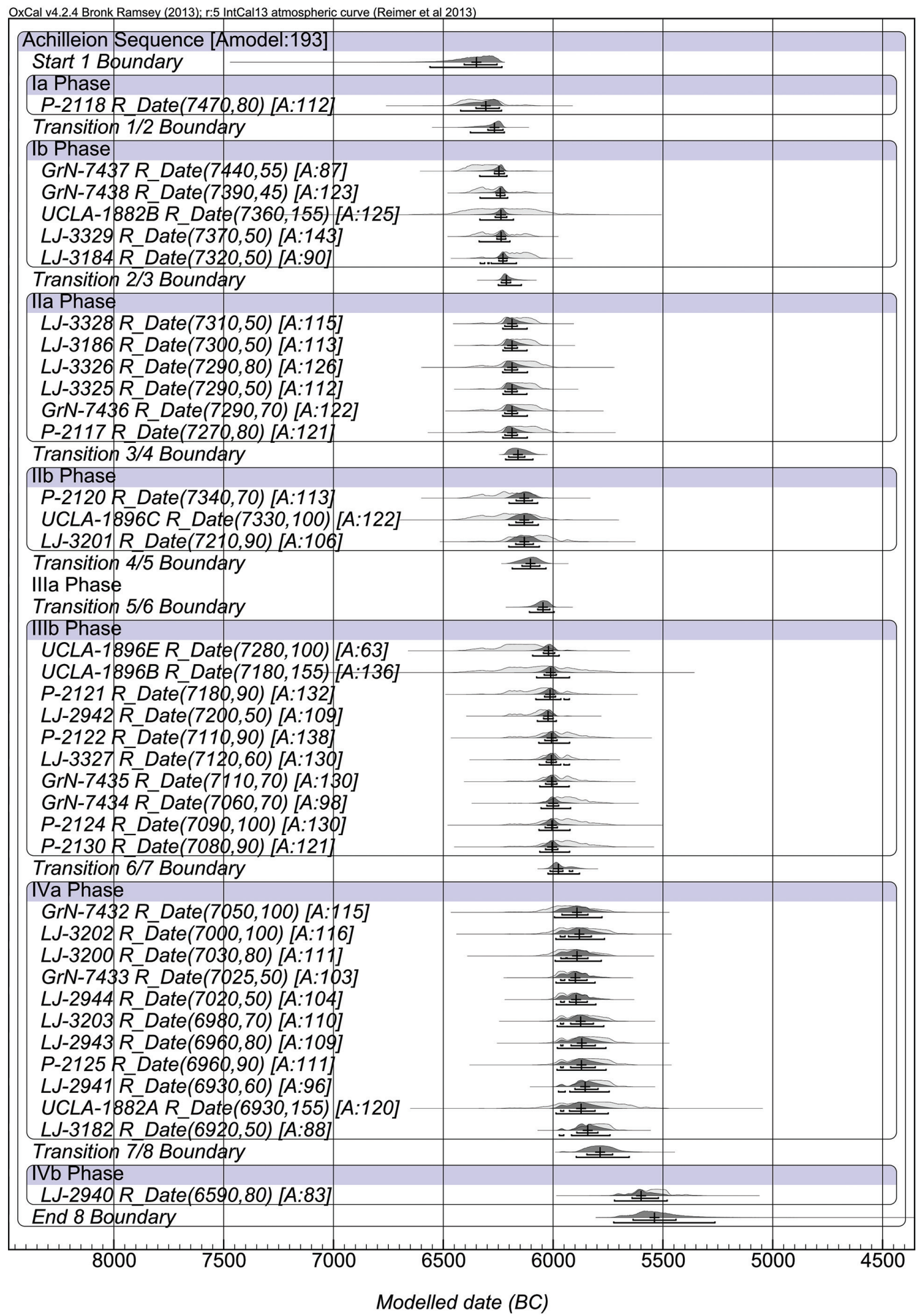

Fig. 10. Achilleion: dates modelled statistically according to the seven phases Achilleion Ia to IVb (excluding two dates with huge standard deviations from a test pit) (all dates from Gimbutas 1989). 
somewhat younger phase of the upper strata, with so-called 'Cardium' pottery, with impressions made with an instrument. These interpretations are not grounded on sufficient stratigraphic observations (note that, precisely at the transition from the EN to the MN, $60-70 \mathrm{~cm}$ are missing from the stratigraphic sequence in Otzaki: Milojčić 1971.13,15; Pl. V). Moreover, the division into two sub-phases relies on only few inventories, mainly on material deriving from sites in north-eastern and western Thessaly. It is especially in these parts of Thessaly that the defining pottery style for the EN III, Impresso pottery, occurs. Farther south (in Achilleion and Sesklo) this kind of pottery appears infrequently, and fades out completely south of the Spercheios valley. This may be the reason why Gimbutas proposed an alternative separation: she not only rejected the division of the EN into three stages and suggested an early start to the MN at 6100 cal BC instead (Gimbutas 1989. Fig. 3.4 and Fig. 3). She even arrived at completely different conclusions concerning impressed pottery styles: based on less than 20 sherds, she suggested that first the punctuated/stabbed Impresso pottery appeared in phase Achilleion IIIb and stopped with
Phase IVa, when fingernail impressions were applied to pots (Gimbutas et al. 1989.92 and Tab. 5.5).

Irrespective of styles, the radiocarbon dates for the levels with Impresso pottery both in Achilleion (phase IIIb) and in Otzaki (Area III, upper level) are of the same period, between 6060/6030 and 5880/ $5830 \mathrm{cal} \mathrm{BC}$ (Figs. 10 and 11).

Therefore, the transition between the two periods of the EN and the MN can be dated in Thessaly to around $6000 \mathrm{cal} \mathrm{BC}$, but the correspondence between relative and absolute chronology is currently not satisfactorily solved. Only new and sound stratigraphic evaluations will contribute to a better definition of this transition. For the time being, a division into three EN-phases can be advocated.

That the MN started at the latest in $5900 \mathrm{cal} \mathrm{BC}$ is corroborated by dates known since the 1990s from the Cyclops Cave, Theopetra and Platia Magoula Zarkou; this view is further supported by dates obtained from Sykeon (Figs. 12 and 13). Also, new dates from the western fringes of the Pindus Mountains

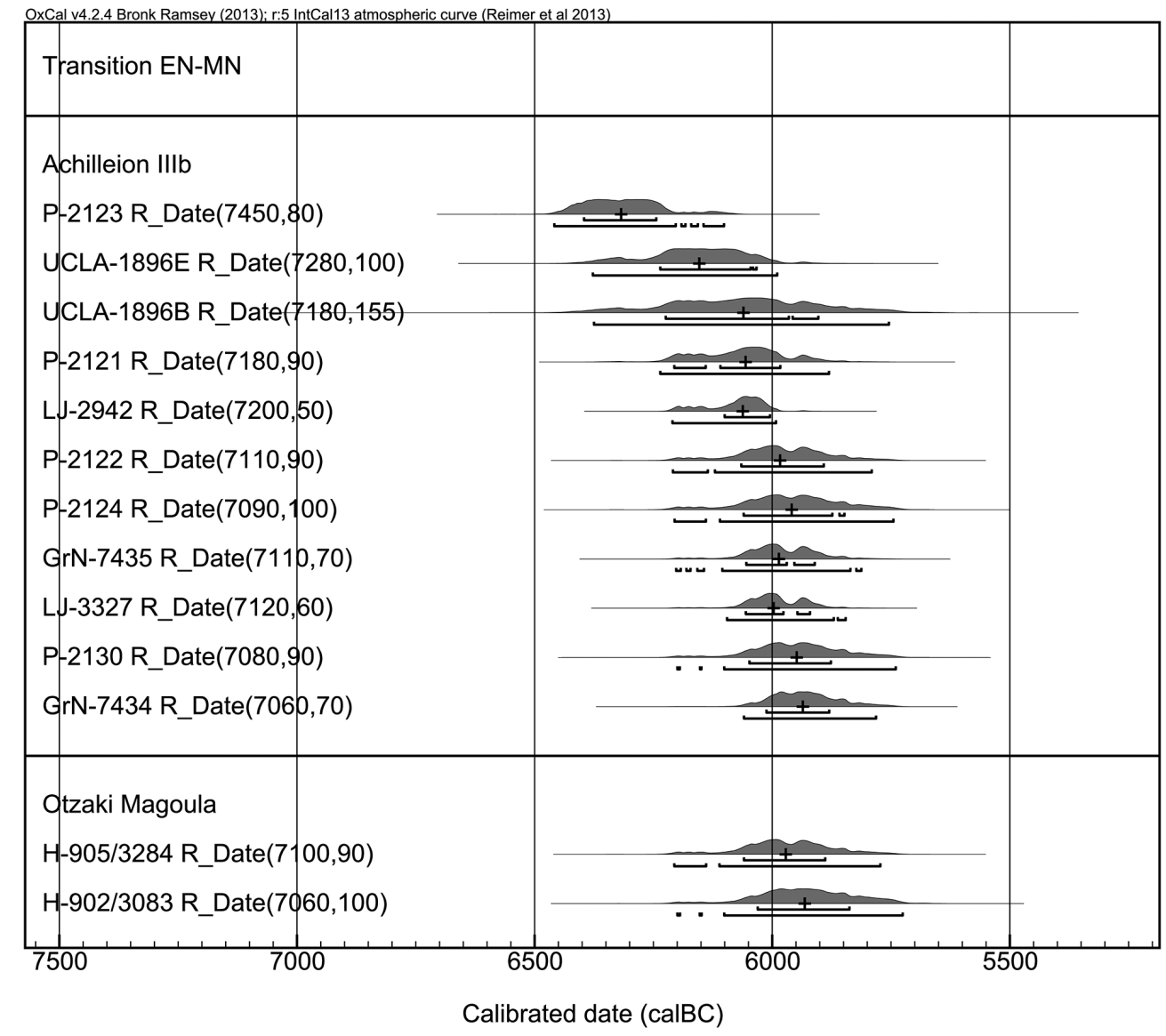

Fig. 11. Dates for the transition EN-MN (the modelled dates of phase Achilleion IIIb in Fig. 10 resulted between 6070-5980 cal BC, corresponding well with the two dates from Otzaki Magoula; see Reingruber 2008.270). 
and from the southernmost tip of the Thessalian Plain in northern Phthiotis (now included in the municipality of Domokos) confirm this view: four dates from Lake Plastiras fall into the first quarter of the $6^{\text {th }}$ millennium $\mathrm{BC}$, as is the case also with two charcoal dates obtained from Imvrou Pigadi (Fig. 14). From the latter site, another four dates obtained by thermoluminescence dating do not contradict this view (Kyparissi-Apostolika et al. 2016.38), despite the huge error margins of 500 years inherent to the method (Tab. 4). The reliable sequence consisting of six dates from Koutroulou Magoula confirms that the beginning of the MN occurred early in the $6^{\text {th }}$ millennium BC (Hamilakis et al. in print).

Therefore, a first phase of the MN can be securely dated to between $6000 / 5900-5750 \mathrm{cal} \mathrm{BC}$. For the ensuing centuries, fewer dates are available, but those from Achilleion and Theopetra can be followed up until $5500 \mathrm{cal} \mathrm{BC}$. The 500 -year duration of this pe-

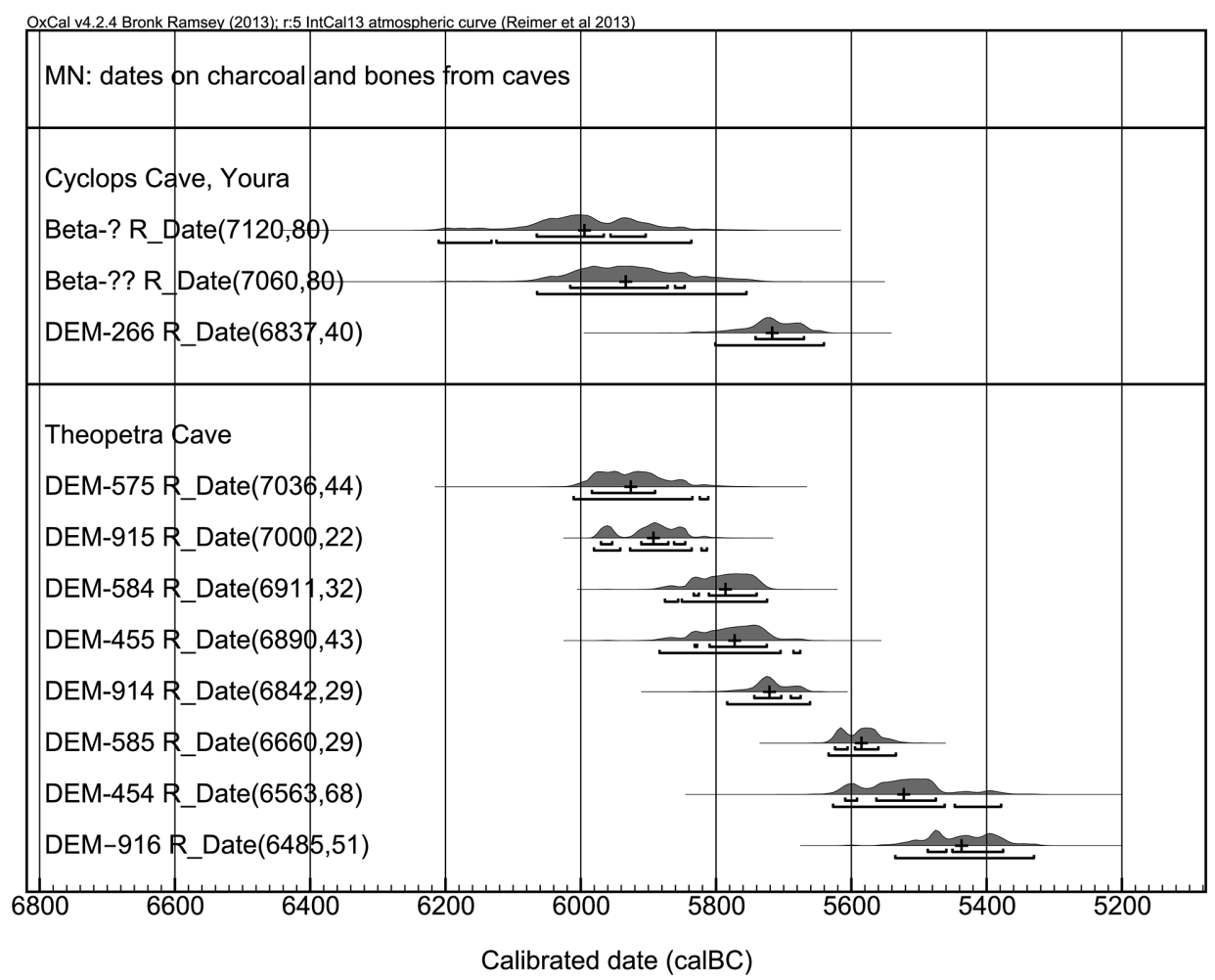

Fig. 12. Charcoal and bone samples from the MN levels in the Cyclops Cave on Youra (compare Facorellis et al. 1998.Tab. 1; Trantalidou 2003.157) and from Theopetra Cave (Facorellis et al. 2001).

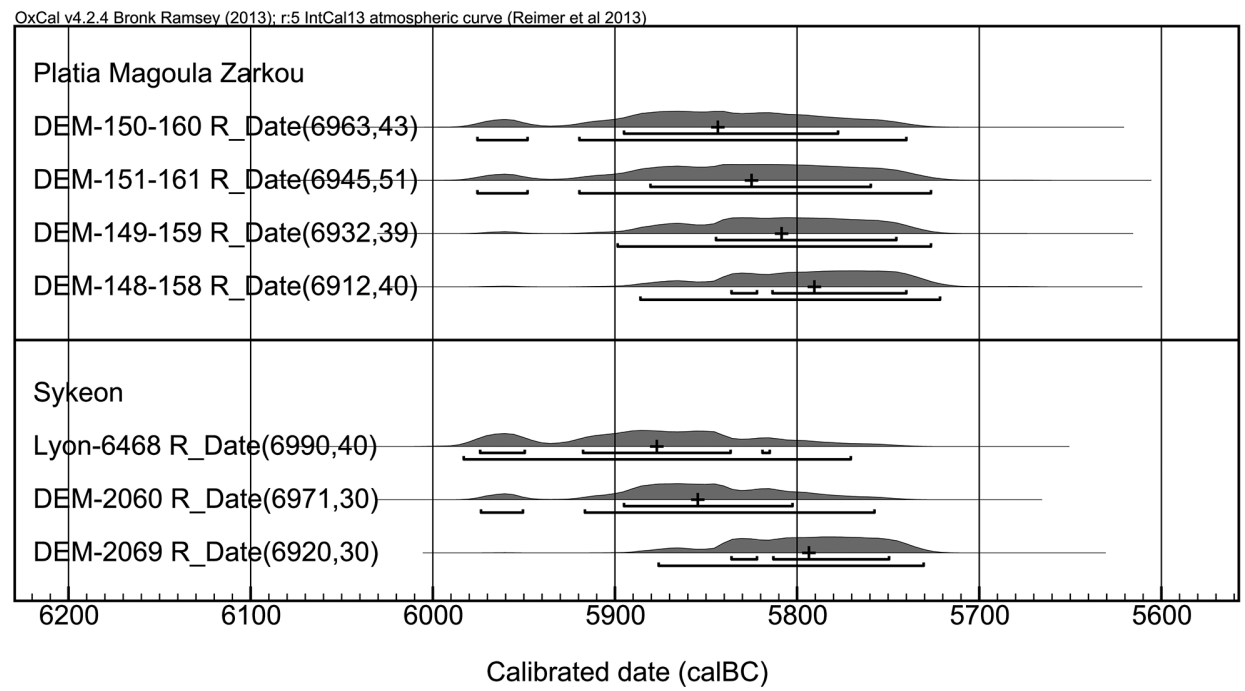

Fig. 13. Platia Magoula Zarkou and Sykeon: dates from the MN levels (Gallis 1990.214, Tab. 1; Maniatis et al. 2016.63-64, Tab. 1). 


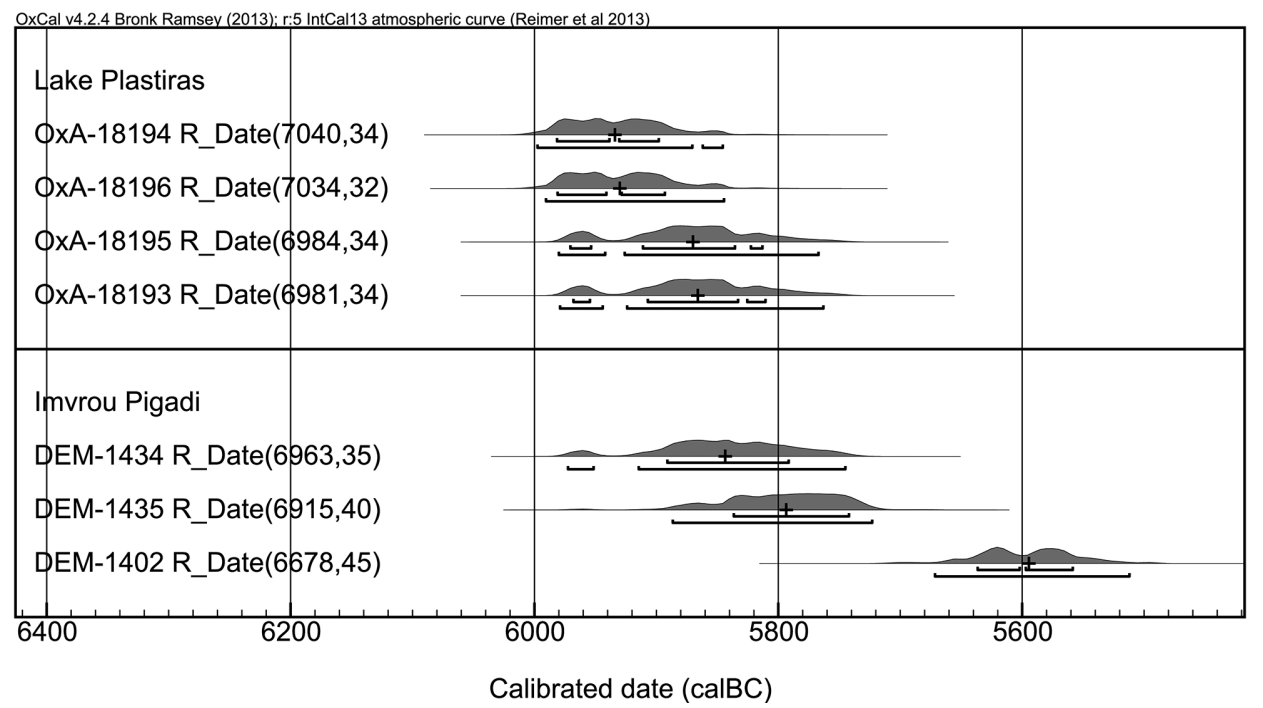

Fig. 14. New dates for the MN from western Thessaly and the northern Phthiotis (Kyparissi-Apostolika et al. 2009; Kyparissi-Apostolika 2012.436).

riod must therefore be shifted by 200 years from $5800-5300$ cal BC to $6000 / 5900-5500$ cal BC. Additionally, the single and free-floating dates from Argissa Magoula and Agios Petros (Efstratiou 1985.167) do corroborate a dating of the MN to the first half of the $6^{\text {th }}$ millennium $\mathrm{BC}$.

\section{The MN-LN transition and the LN I (5500-5000 cal BC)}

The hitherto known sequences from MN sites suggest that this period ended around or even shortly before $5500 \mathrm{cal} \mathrm{BC}$. There is only one date from Ses-

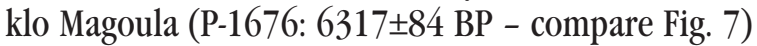
that, due to its big standard deviation and due to a plateau in the calibration curve, covers almost 300 years at $1 \sigma(5470-5210 \mathrm{cal} \mathrm{BC})$ and at $2 \sigma$ more than 400 years $(5480-5060 \mathrm{cal} \mathrm{BC})$. It is certainly not suitable for defining the end of the MN at $5300 \mathrm{cal} \mathrm{BC}$.

On the other hand, the oldest dates for the LN I obtained in Theopetra, Prodromos-Magoula Agios Ioan- nis, and Makrychori (Fig. 15) fit exactly into the centuries 5500-5300 cal BC, supporting the conclusion that the $\mathrm{LN}$ had already started at $5500 \mathrm{cal} \mathrm{BC}$. Nevertheless, in the whole of Southeastern Europe, dates for the centuries between 5500 and $5300 \mathrm{cal} \mathrm{BC}$ are generally only few in number. In relative chronological terms, this is the time of the Tsangli-Larissa culture (Gallis 1987), with major transformations in many parts of the Balkans and Central Europe (beginning of Karanovo III, Vinča A and LBK). In addition, in terms of radiocarbon dates, the final two centuries of the $6^{\text {th }}$ millennium in Thessaly are only poorly represented. No conclusive absolute dates are available yet for the (pottery) culture of Arapi.

\section{The LN I-LN II transition and the LN II (5000- 4500 cal BC)}

The beginning of the LN II in the first century of the $5^{\text {th }}$ millennium is poorly attested by radiocarbon dates. From Otzaki Magoula, after which all the phases of the LN II have been labelled (Hauptmann 1981; Hauptmann, Milojčić 1969),

\begin{tabular}{|c|c|c|c|c|c|c|c|c|}
\hline $\begin{array}{l}\text { Lab. } \\
\text { no. }\end{array}$ & $\begin{array}{l}\text { Date } \\
\text { BP }\end{array}$ & $\begin{array}{l}\text { Age } \\
\text { BC }\end{array}$ & $\begin{array}{c} \pm \\
\text { years }\end{array}$ & $\begin{array}{l}\text { ED } \\
\text { (Gy) }\end{array}$ & $\underset{(\mathrm{ppm})}{U}$ & $\begin{array}{c}\text { Th } \\
\text { (ppm) }\end{array}$ & $\begin{array}{c}\mathrm{K} \\
(\%)\end{array}$ & $\begin{array}{c}\text { DR } \\
\text { (Gy/ka) }\end{array}$ \\
\hline$\overline{\mathrm{Ml} 5}$ & 7177 & 5164 & 515 & $\begin{array}{l}28.86 \\
(2.09)\end{array}$ & $\begin{array}{c}5.43 \\
(0.14)\end{array}$ & $\begin{array}{c}6.18 \\
(0.18)\end{array}$ & $\begin{array}{c}1.81 \\
(0.02)\end{array}$ & 4.021 \\
\hline$\overline{\mathrm{MI6}}$ & 7284 & 5271 & 533 & $\begin{array}{l}30.51 \\
(2.26)\end{array}$ & $\begin{array}{c}6.62 \\
(0.15)\end{array}$ & $\begin{array}{l}7.46 \\
(0.15)\end{array}$ & $\begin{array}{c}1.29 \\
(0.02)\end{array}$ & 4.188 \\
\hline Ml7 & 7269 & 5256 & 521 & $\begin{array}{l}31.27 \\
(2.32)\end{array}$ & $\begin{array}{c}6.02 \\
(0.15)\end{array}$ & $\begin{array}{c}7.58 \\
(0.18)\end{array}$ & $\begin{array}{c}1.71 \\
(0.02)\end{array}$ & 4.301 \\
\hline $\mathrm{Ml} 12$ & 6808 & 4795 & 499 & $\begin{array}{l}31.69 \\
(2.51)\end{array}$ & $\begin{array}{c}7.43 \\
(0.11)\end{array}$ & $\begin{array}{c}7.68 \\
(0.14)\end{array}$ & $\begin{array}{c}1.47 \\
(0.02)\end{array}$ & 4.655 \\
\hline
\end{tabular}

no organic material has been sampled from these levels. Therefore, little can be said about the transition from the LN I to LN II. Moreover, the pottery sequences Otzaki $\mathrm{A}, \mathrm{B}$ and $\mathrm{C}$ cannot be verified with the help of radiocarbon sequences. Most importantly, a first glimpse into the absolute dating of these phases has been made possible thanks to a sequence of eight dates from the sites of Mandra (Fig. 16). Judg-
Tab. 4. Thermoluminiscence (TL) dates from Imvrou Pigadi (Kyparissi-Apostolika et al. 2016.38). 
ing by the median values, the site may have been inhabited between 4900 and $4700 \mathrm{cal} \mathrm{BC}$, during the earlier part of the LN II (Toufexis et al. 2009.113; Karagiannopoulos 2016.388; Maniatis et al. 2016.Tab. 1). From the later part of the LN II, new ${ }^{14} \mathrm{C}$ dates were obtained recently from rescue excavations at the famous site of Rachmani, confirming its date to the $\mathrm{LN} \mathrm{II} \mathrm{and} \mathrm{the} \mathrm{FN/Ch} \mathrm{(Fig.} \mathrm{17).} \mathrm{Also,} \mathrm{the} \mathrm{new} \mathrm{dates}$ from Prodromos-Magoula Agios Ioannis and from $\mathrm{Va}$ silis fall according to their medians between $c .4700$ and $4600 \mathrm{cal} \mathrm{BC}$. The pottery from the latter site is mainly of the 'Otzaki' and 'local Dimini' styles.

That the LN II indeed ended around or shortly after 4600 or rather around $4500 \mathrm{cal} \mathrm{BC}$ is corroborated by the sequence from Pevkakia Magoula in Magnesia

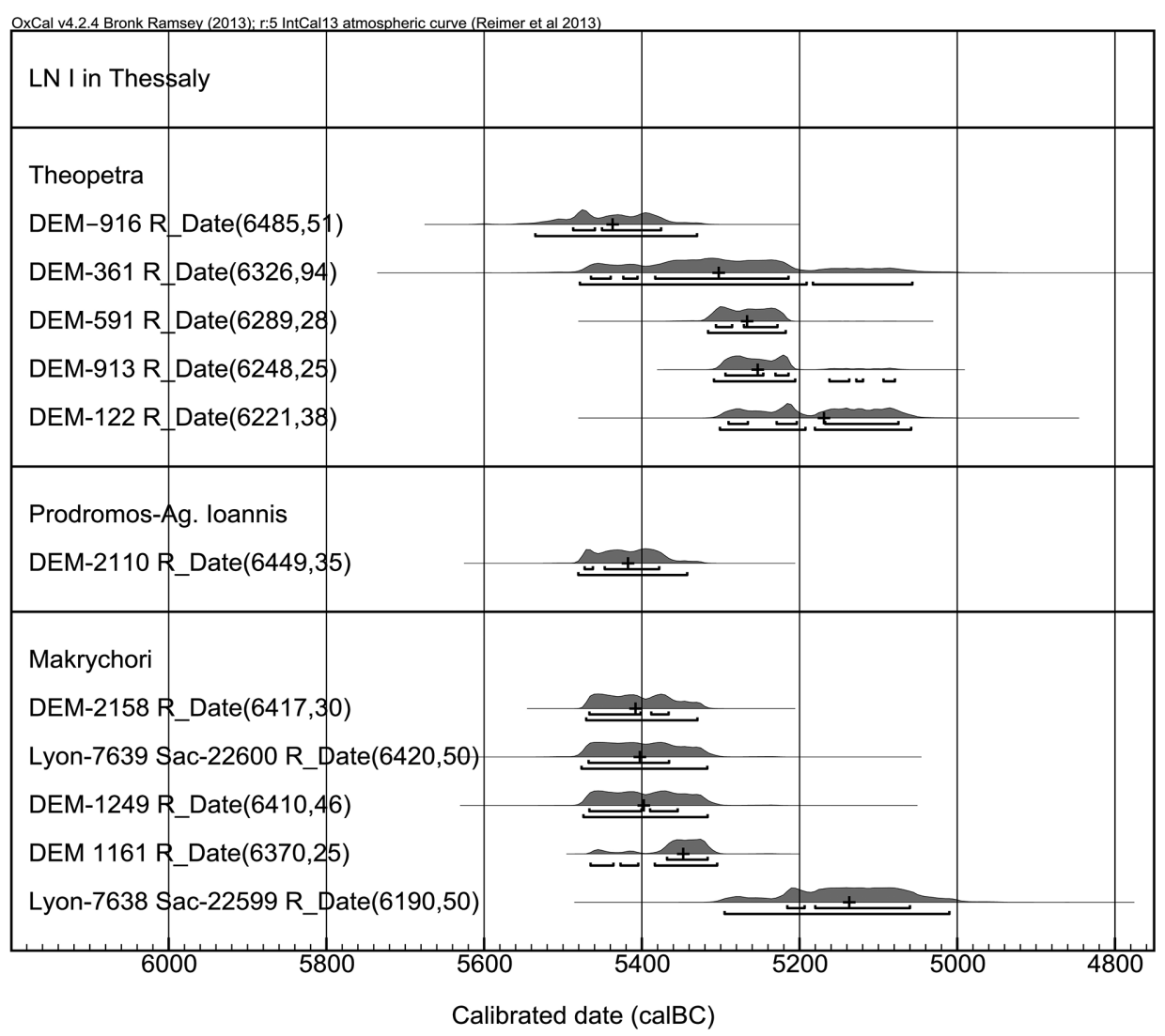

Fig. 15. Thessalian sites with dates from the LN I (Maniatis et al. 2016.Tab. 1; Reingruber, Thissen 2016).

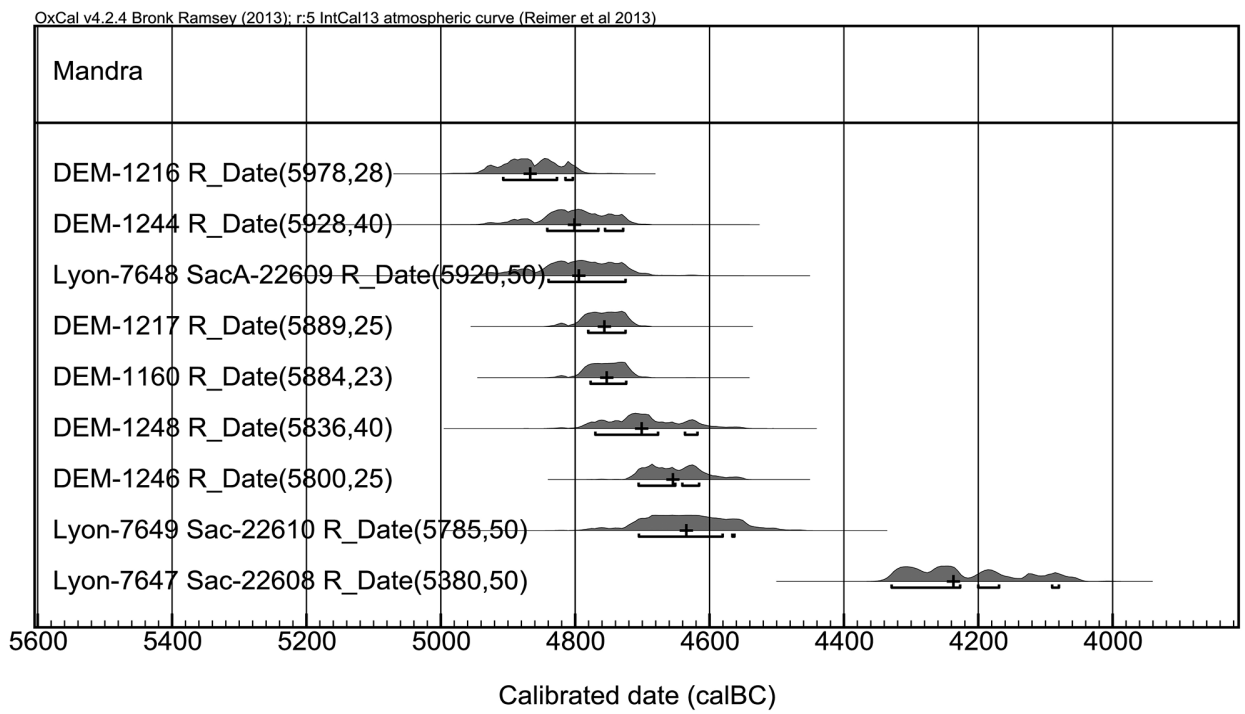

Fig. 16. Mandra: radiocarbon dates from levels I-III of the LN II and from level V of the FN/Ch (Toufexis 2000; forthcoming). 
(Weißhaar 1989.139) for which ten dates were published as 'uncalibrated BC'. Therefore, the value 1950 must be added to the given dates to obtain the initial BP-value. When modelled, the six dates for the end of the phase fall within the range 4600 and 4500 cal BC (Fig. 18).

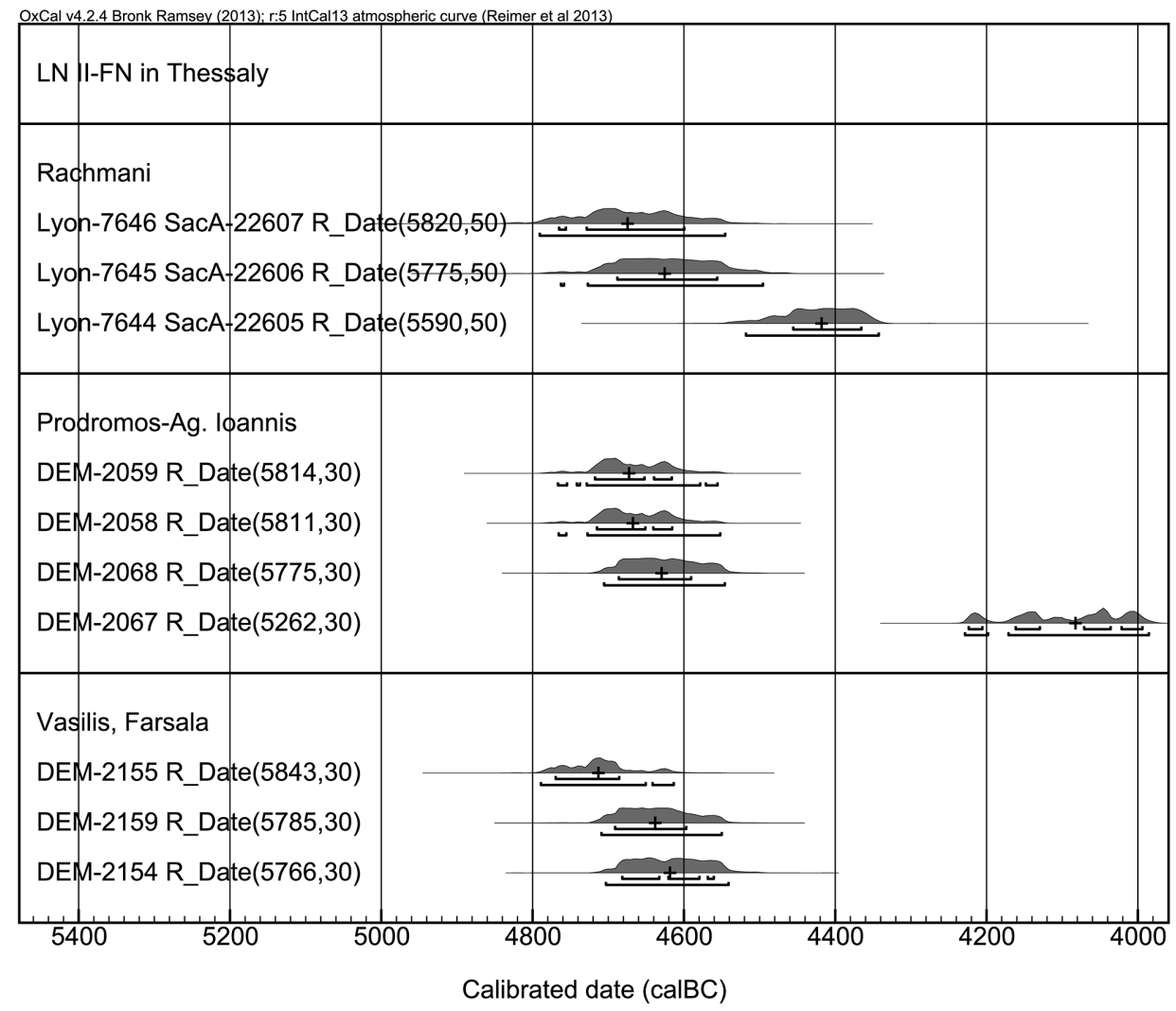

Fig. 17. Thessalian sites with eight dates from the LN II before $4500 \mathrm{cal} B C$ and two dates from the FN/Ch after 4500 cal BC (Maniatis et al. 2016.Tab. 1).

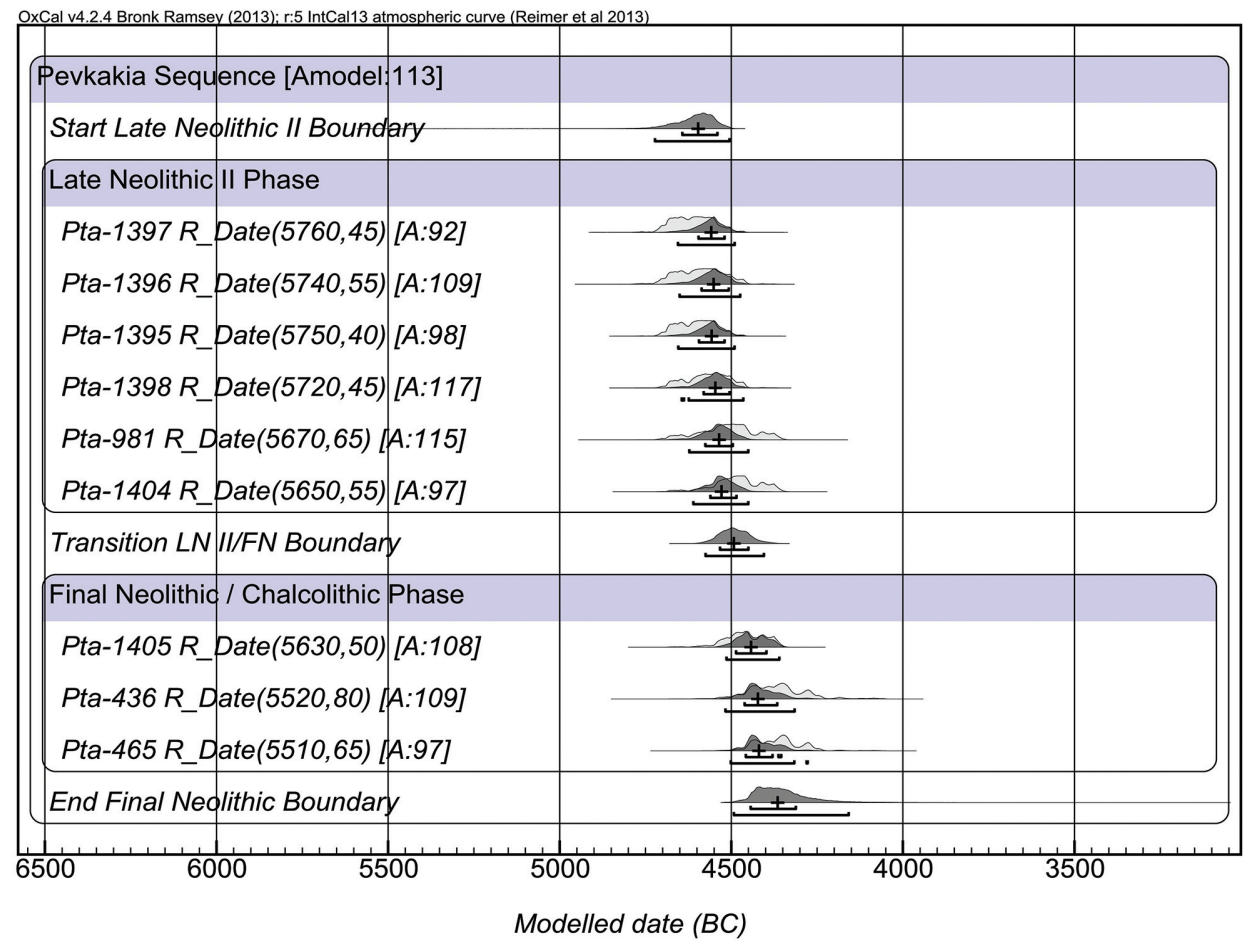

Fig. 18. Pevkakia Magoula: modelled dates from the end of the LN II and the early FN/Ch, excluding the outlier Pta-435 (Weißhaar 1989; Reingruber, Thissen 2016). 


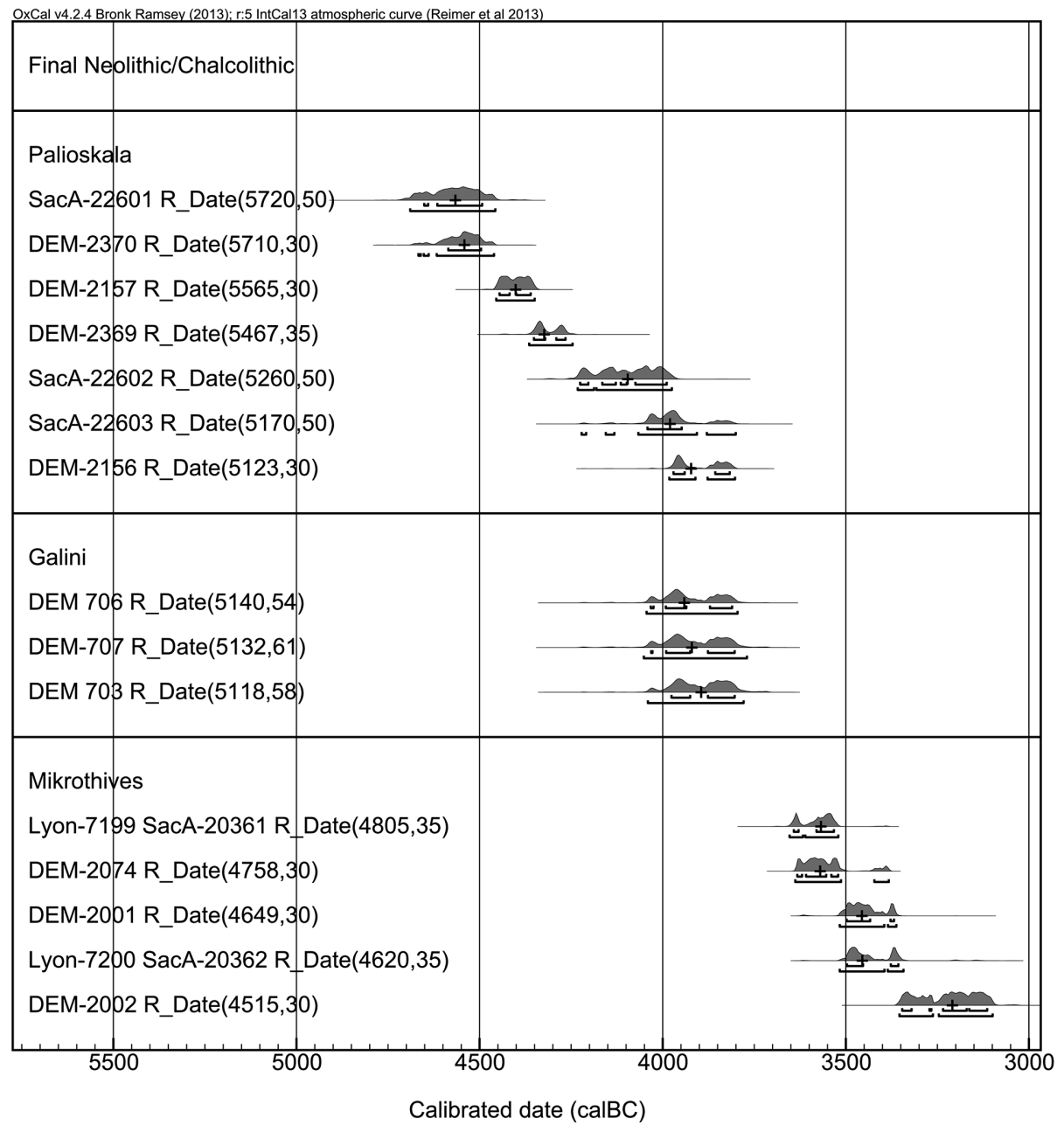

Fig. 19. Radiocarbon dates for the FN/Ch between 4550 and 3300 cal BC (Toufexis 2016; Maniatis et al. 2016).

The transition from the LN to the FN/Ch around 4500 cal $\mathrm{BC}$ is also supported by the new dates from Palioskala (Toufexis 2016.371, Tab. 1; Maniatis et al. 2016.Tab. 1): the two oldest dates shortly before 4500 cal BC belong to the LN II (Fig. 19).

Although the terminology for the 'Dimini culture' evokes consistency and continuity among the different phases and sub-phases, only the final stage of the 'Dimini culture' is represented in the excavated levels of the eponymous site. One single date with a huge standard deviation $5630 \pm 150 \mathrm{BP}$ (Lab. No. not given) covers the time between 4680 and $4340 \mathrm{cal}$ $\mathrm{BC}$ and is therefore not suitable for evaluation (Reingruber, Thissen 2016).

\section{The Final Neolithic/Chalcolithic (4500-3300 cal BC)}

In a pan-regional, Southeastern European perspective, the terminology for the $5^{\text {th }}$ and $4^{\text {th }}$ millennia is rather contradictory. Between 4600/4500 and 4200/
$4000 \mathrm{cal} \mathrm{BC}$, the heyday of the Copper Age or Eneolithic in the Balkans (with the cultures Gumelniţa, Karanovo VI and Varna) had been reached (Todorova 1995). Beside the appearance of innovative techniques mostly related to the exploitation of metals (copper, gold and - only in the Aegean - silver), social transformations also allow a separation of this period from the proper Neolithic Age (Souvatzi 2008). Therefore, in this article the term Chalcolithic is used synonymously for Final Neolithic.

In Thessaly, the final dates for the LN 'Dimini culture' around $4500 \mathrm{cal} \mathrm{BC}$ also define the start of the ensuing 'Rachmani culture'. This is confirmed by the modelled sequence from Pevkakia Magoula, where three samples date the FN/Ch to 4500-4300 cal BC (Fig. 18). Also, single dates from the sites of Rachmani and Prodromos-Magoula Agios Ioannis fall into the second half or even the end of the $5^{\text {th }}$ millennium (Fig. 17). The sample for the youngest date from Mandra (Fig. 16) was derived from a pit dug into the fill of a LN ditch. However, this youngest phase is re- 
presented mainly by surface material.

In the Balkans, shortly before 4000 cal BC, the long-lived tell-sites were abandoned. Information for the following centuries of the Transitional Period (Todorova 1995.89) is meagre (but compare Tsirtsoni 2016). Also, in the Northern Aegean (Maniatis 2014; Maniatis et al. 2014) and in Thessaly the time around and after $c .4200 / 4000$ cal BC is extremely difficult to grasp. The scarcity of dates until $c .3750$ cal BC coincides partly with a huge plateau in the calibration curve that impedes a precise determination of single dates. In this plateau fall the three youngest dates from Palioskala (Toufexis 2016; Fig. 19). Judging by these dates and the dates from Galini, this phase of the FN/Ch probably lasted until 3750 cal BC (yet the stratigraphical sequence in Galini is complicated by post-depositional disturbances: Toufexis 1999). 4200/4000 cal BC can provisionally be regarded as a turning point also for Thessaly, but the final evaluation of the Palioskala site will certainly shed more light on this still dark chapter in Thessalian prehistory (a period that may have been coeval with the Transitional Period in Bulgaria). With the dates from Mikrothives, a final stage of the FN/Ch period can be contoured between 3750 and $3300 \mathrm{cal} \mathrm{BC}$. Therefore, for the moment it is impossible to go further than to state that three groups of dates from Palioskala, Galini and Mikrothives might reflect three stages of the FN/Ch: at 4500$4200 / 4000 \mathrm{cal} \mathrm{BC}$, at $4200 / 4000-3750 \mathrm{cal} \mathrm{BC}$ and at 3750-3300 cal BC. More reliable dates are definitely needed to fill in the huge gaps and to understand the transition to the Early Bronze Age (and here again, Palioskala will offer valuable insights).

\section{Discussion}

From Thessaly, only two sites provided radiocarbon sequences suitable for statistical analysis (Achilleion and Pevkakia Magoula). Certainly, Bayesian modelling cannot be self-sufficient: it is an instrument, a method for obtaining more refined information on the duration of phases, especially on their boundaries. It is self-evident that the more data available for future analysis, the more reliable the results will be. Therefore, all conclusions based on this method are provisional and subject to continuous adjustments.

The two modelled sequences from Thessaly cover vital parts of the Neolithic Age: the sequence from Achilleion spans major parts of the EN and the MN, whereas the sequence from Pevkakia Magoula gave reliable results for the $\mathrm{LN}-\mathrm{FN} / \mathrm{Ch}$ transition. In addition to giving a good orientation for the probable duration of specific phases, these two sequences serve as TAQ and TPQ for the phases preceding and following them. Apart from this, they are especially helpful also regarding the appraisal of single, freefloating dates (both old and new dates available from different Thessalian sites). Together they contribute to a better understanding not only of the duration of periods and phases, but also of the transitions between them. Nevertheless, as has been shown for the early achievements of radiocarbon based chronological schemes, generalisations can always lead to imprecise results. This holds also true for this paper, especially regarding the $\mathrm{LN}$ and $\mathrm{FN} / \mathrm{Ch}$. To sum up, some provisional results are presented in Table 5.

The few and often ambiguous dates hamper a better interpretation of boundaries. Therefore, a more re- 


\begin{tabular}{|lll|}
\hline $\begin{array}{l}\text { Abs. dates } \\
\text { cal BC (rounded) }\end{array}$ & $\begin{array}{l}\text { Archaeological } \\
\text { periods and phases }\end{array}$ & Sites \\
\hline $7000-6600$ & Final Mesolithic & Theopetra Cave, Cyclops Cave \\
\hline $6600-6500$ & 'Initial Neolithic' & - (Identified mainly in circum-Aegean coastal and/or hilly areas) \\
\hline $6500-6300$ & EN I & Argissa M., Sesklo M. \\
\hline $6280-6070$ & EN II & Achilleion I-II, Sesklo, Larissa-Neraida \\
\hline $6070-5980$ & EN III / MN I & Achilleion IIIb, Otzaki \\
\hline $5980-5750$ & MN I & Achilleion IVa, Theopetra, Cyclops Cave, Koutroulou M., Platia M. Zarkou, \\
\hline$\underline{5750-5600}$ & MN II & Sykeon, Imvrou Pigadi, Lake Plastiras \\
\hline $5600-5500$ & MN III & Sesklo, Theopetra, Ag. Petros \\
\hline $5500-5300$ & LN I (early) & Achilleion IVb, Sesklo, Theopetra \\
\hline $5300-5000$ & LN I (late) & Theopetra, Makrychori, Prodromos-M. Ag. Ioannis \\
\hline $4900-4700$ & LN II (early) & Mandra, Makrychori \\
\hline $4700-4500$ & LN II (late) & Rachmani, Prodromos-M. Ag. Ioannis, Vasilis, Pevkakia M., \\
\hline $4500-4250$ & FN (Chalcolithic) & Rachmani, Pevkakia M., Palioskala, Mandra \\
\hline $4250-3750$ & FN (Chalcolithic) & Palioskala, Galini \\
\hline $3750-3300$ & FN (Chalcolithic) & Mikrothives \\
\hline
\end{tabular}

\section{Tab. 5. General appraisal of periods and phases in Thessaly.}

fined delimitation of phases in terms of decades, not in terms of centuries, is impossible. In some cases, especially at the beginning and the end of the Neolithic, the calibration curve itself impedes the acquisition of more detailed results. Successive wiggles often form flat portions (so-called plateaus) that cover many centuries. They greatly influence the appraisal of certain dates, especially those in the Mesolithic-Neolithic transition between 7000 and 6600 cal BC (Fig. 20). At first sight, these dates seem to support the chronology with the Neolithic starting at $7000 \mathrm{cal} \mathrm{BC}$ (compare 'Date 1'). However, when such dates are modelled in line with methodologically well-founded procedures, their duration can be better evaluated. As has been shown by Bernhard Weninger et al. (2014.Figs. 12-13), the Neolithic starts at the Ulucak and Çukuriçi Höyük sites around $6650 \mathrm{cal} \mathrm{BC}$, not at $7000 \mathrm{cal} \mathrm{BC}$. Dates from Knossos X, Sarakenos and Franchthi, especially those obtained on short-lived grains, confirm this appraisal (Reingruber 2015; Reingruber, Thissen 2016). For Thessaly all dates available at the moment suggest that the Neolithic way of life started there only well after this plateau ended, around $6500 \mathrm{cal} \mathrm{BC}$.
Other plateaus also occur again during the centuries preceding major transitions: this is the case before the transition from the EN to the MN ('Date 2') and before the LN I to LN II transition ('Date 3'). The interpretation of dates is greatly influenced by the plateau at the end of the $5^{\text {th }}$ millennium ('Date 4'): these plateaus certainly distort to a certain degree the interpretation of the calibrated dates, especially when only single dates are available. Many more dates are needed to control for these shortcomings better, comparable to the dates obtained in Catalhöyük (Bayliss et al. 2015.Tab. 1) or Uivar (Schier et al. 2016).

The authors would like to thank Laurens Thissen for fruitful discussions and Emily Schalk for language editing. We further thank the two anonymous reviewers for their feedback, especially regarding remarks related to terms deriving from relative chronological approaches as based on pottery sequences.

\section{References}

Alram-Stern E. 1996. Die ägäische Frühzeit, 2. Serie, Forschungsbericht 1975-1993, 1. Band. Das Neolithikum in Griechenland mit Ausnahme von Kreta und Zypern. Veröffentlichungen der Mykenischen Kommission 16. Wien.
Alram-Stern E., Dousougli-Zachos A. 2015. Die deutschen Ausgrabungen 1941 auf der Visviki-Magula/Velestino. Die neolithischen Befunde und Funde. Beiträge zur urund frühgeschichtlichen Archäologie des Mittelmeer-Kulturraumes 36. Habelt. Bonn. 
Anetakis M. 2012. Sinoikia Neraida, odos Ikarias 80, 0ikopedo Papageorgiou. Archaiologikon Deltion 67, Chroni$k a$ (forthcoming). (in Greek)

Andreou St., Fotiadis M. and Kotsakis K. 1996. Review of Aegean Prehistory V: The Neolithic and Bronze Age of Northern Greece. American Journal of Archaeology 100: 537-597.

Arvanitopoulos A. S. 1910. Anaskafi kai erevnai en Thessalia. Praktika Archaiologis Etaireias 1910: 168-264. (in Greek)

Bayliss A., Brock F., Farid S., Hodder I., Southon J. and Taylor R. E. 2015. Getting to the bottom of it all: A bayesian approach to dating the start of Çatalhöyük. Journal of World Prehistory 28(1): 1-26.

Béquignon Y. 1932. Études Thessaliens. Bulletin de Correspondance Hellénique 56: 89-191.

Bronk Ramsey C. 2009. Bayesian analysis of radiocarbon dates. Radiocarbon 51(1): 337-360.

Coleman J. E. 1992. Greece, the Aegean and Cyprus. In R. W. Ehrich (ed.), Chronologies in Old World Archaeology, Vol. II. The University of Chicago Press. Chicago and London: 203-229.

Efstratiou N. 1985. Agios Petros, a Neolithic Site in the Northern Sporades. Aegean Relationships during the Neolithic of the $5^{\text {th }}$ Millennium. British Archaeological Reports IS 241. Archaeopress. Oxford.

Facorellis Y., Maniatis Y. and Kromer B. 1998. Apparent ${ }^{14} \mathrm{C}$ Ages of Marine Mollusk Shells from a Greek Island: Calculation of the Marine Reservoir Effect in the Aegean Sea. Radiocarbon 40: 963-973.

Facorellis Y., Kyparissi-Apostolika N. and Maniatis Y. 2001. The cave of Theopetra, Kalambaka: radiocarbon evidence for 50,000 years of human presence. Radiocarbon 43: 1029-1048.

Facorellis Y., Vardala-Theodorou E. 2015. Sea surface radiocarbon reservoir age changes in the Aegean Sea from about 11,200 BP to present. Radiocarbon 57(3): 491-503.

Gallis K. 1987. Die stratigraphische Einordung der Larisa Kultur: eine Richtigstellung. Prähistorische Zeitschrift 62: 147-163. (in Greek)

1990. IE' Ephoreia Proistorikon kai Klassikon Archaiotiton. Archaiologikon Deltion 45, Chronika (1995): 212-214.
Gimbutas M. 1974. Achilleion: A Neolithic Mound in Thessaly; Preliminary Report on 1973 and 1974 Excavations. Journal of Field Archaeology 1(3/4): 277-302.

1989. Chronology. In M. Gimbutas, S. Winn and D. Shimabuku (eds.), Achilleion: A Neolithic Settlement in Thessaly, Greece, 6400-5600 BC. Monumenta Archaeologica 14. Cotsen Institute of Archaeology Press. Los Angeles: 23-31.

Grundmann K. 1932. Aus neolithischen Siedlungen bei Larisa. Athener Mitteilungen 57: 102-123.

Hamilakis Y., Kyparissi-Apostolika N., Loughlin T., Carter T., Cole J., Facorellis G., Katsarou S., Kaznesi A., Pentedeka A., Tsamis V. and Zorzin N. in print. Koutroulou Magoula in Fthiotida, Central Greece: A Middle Neolithic tell site in context. In A. Sarris, E. Kalogiropoulou, T. Kalayici and E. Karimali (eds.), Communities, Landscapes and Interaction in Neolithic Greece. Proceedings of the International Conference Rethymno 29-30 May 2014.

Hauptmann H. 1981. Das Späte Neolithikum und das Chalkolithikum. Die deutschen Ausgrabungen auf der Otzaki-Magula in Thessalien. Beiträge zur ur- und frühgeschichtlichen Archäologie des Mittelmeer-Kulturraumes, Band 21. Habelt. Bonn.

2015. Vorwort des Herausgebers. In E. Alram-Stern, A. Dousougli-Zachos. Die deutschen Ausgrabungen 1941 auf der Visviki-Magula/Velestino. Die neolithischen Befunde und Funde. Beiträge zur ur- und frühgeschichtlichen Archäologie des Mittelmeer-Kulturraumes 36. Habelt. Bonn: 1-5.

Hauptmann H., Milojčić V. 1969. Die Funde der frühen Dimini-Zeit aus der Arapi-Magula Thessalien. Beiträge zur ur- und frühgeschichtlichen Archäologie des Mittelmeer-Kulturraumes 9. Habelt. Bonn.

Karagiannopoulos Chr. 2016. Prodromos Karditsas, Magoula Agios Ioannis. A prehistoric settlement in the western Thessalian Plain. In Z. Tsirtsoni (ed.), The Human Face of Radiocarbon: Reassessing chronology in prehistoric Greece and Bulgaria, 5000-3000 cal BC. Travaux de la Maison de l'Orient et de la Méditerranée - Série recherches archéologiques. Lyon: 381-393.

Kyparissi-Apostolika N. 2000a. The Mesolithic/Neolithic Transition in Greece as evidenced by the Data at Theopetra Cave in Thessaly. Documenta Praehistorica 27: 133140.

2000b. Theopetra Cave: Twelve Years of Excavation and Research 1987-1998. Proceedings of the International Conference, Trikala, 6-7 November 1998. Institute for Aegean Prehistory. Athens. 
2012. Indications of the presence of Middle Neolithic pottery kilns at Magoula Imvrou Pigadi, SW Thessaly, Greece. Documenta Praehistorica 39: 433-442.

in print. "Xana-diabazontas" to neolithiko topio tis ditikis Thessalias: scheseis, allilepidraseis, omoiotites kai diaphores. In Workshop in Honour of Giorgos Chourmouziades, Thessaloniki, 22. May 2015.

forthcoming. Theopetra Cave in Thessaly, Greece. Vol. I, The Neolithic Period.

Kyparissi-Apostolika N., Chatziangelakis L., Apostolikas 0. and Alexiou N 2009. Neolithiki egkatastasi sto oropedio tis Limnis Plastira, Nomou Karditsas: metakiniseis plithysmon tis Thessalikis pediadas se therina boskotopia. In Praktika epistimonikis synantisis, Volos 2009. Archaiologiko Ergo Thessalias kai Stereas Elladas (AETHSE) 3: 97-106. (in Greek)

Kyparissi-Apostolika N., Aidona E. and Polimeris G. S. 2016. Magoula Imvrou Pigadi (Neo Monastiri Phthiotidas): Oi protoi neolithikoi klivanoi. Ektimisi gia ti leitourgia tou stin evriteri neolithiki koinotita tis periochis. In Ta Pharsala kai I evriteri periochi tous. Istorika kai archaiologika dedomena apo tous proistorikous eos tous neoterous chronous, Pharsala 2013. Prakitika Sinedriou Pharsala: 25-38. (in Greek)

Lawn B. 1975. University of Pennsylvania Radiocarbon Dates XVIII. Radiocarbon 17(2): 201-203.

Maniatis Y. 2014. Radiocarbon dating of the major cultural changes in prehistoric Macedonia: Recent developments. In E. Stefani, N. Merousis and A. Dimoula (eds.), $A$ Century of Research in Prehistoric Macedonia 19122012. International Conference Proceedings. Archaeological Museum of Thessaloniki. Thessaloniki: 205-222.

Maniatis Y., Tsirtsoni Z., Oberlin Chr., Darcque P., Koukouli-Chryssanthaki Ch., Malamidou D., Siros T., Miteletsis M., Papadopoulos S. and Kromer B. 2014. Neolithic-Early Bronze Age transition in Southeast Europe. In R. H. Tykot (ed.), Proceedings of the $38^{\text {th }}$ International Symposium on Archaeometry 2010, Tampa, Florida. Open Journal of Archaeometry 2: 5262. doi:10.4081/arc.2014.5262

Maniatis Y., Oberlin C. and Tsirtsoni Z. 2016. Chapter 2. "Balkans 4000": the radiocarbon dates from archaeological contexts. In Z. Tsirtsoni (ed.), The Human Face of Radiocarbon: Reassessing chronology in prehistoric Greece and Bulgaria, 5000-3000 cal BC. Travaux de la Maison de l'Orient et de la Méditerranée-Série recherches archéologiques. Lyon: 41-65.

Maniatis Y., Kotsakis K. 2016. Tracing the spreading of neolithisation in the Aegean with radiocarbon dating. In 23rd Neolithic Seminar Abstract Book. From Chronos to Chronologies. Department of Archaeology, Faculty of Arts, University of Ljubljana. Ljubljana: 11.

Milojčić V. 1950/51. Zur Chronologie der jüngeren Steinzeit Griechenlands. Jahrbuch des Deutschen Archäologischen Instituts 65/66: 1-90.

1956. Die erste präkeramische bäuerliche Siedlung der Jungsteinzeit in Europa. Germania 34: 208-210.

1971. Stratigraphie und Bauten. In V. Milojčić, J. Milojčić - von Zumbusch, Die deutschen Ausgrabungen auf der Otzaki-Magula in Thessalien I. Das frühe Neolithikum. Beiträge zur ur- und frühgeschichtlichen Archäologie des Mittelmeer-Kulturraumes 10-11. Habelt. Bonn: 13-17.

1973. Die C14-Methode im Lichte der komparativ-stratigraphischen Befunde. In UISPP: Actes du VIIIe congres international des sciences préhistoriques et protohistoriques. Beograd 1971. Beograd: 3-11.

Milojčić - von Zumbusch J. 1971. Vorlage der Funde. In V. Milojčić, J. Milojčić -von Zumbusch, Die deutschen Ausgrabungen auf der Otzaki-Magula in Thessalien I. Das frühe Neolithikum. Beiträge zur ur- und frühgeschichtlichen Archäologie des Mittelmeer-Kulturraumes 10-11. Habelt. Bonn: 19-152.

Papathanassopoulos G. A. (ed.) 1996. Neolithic Culture in Greece. N. P. Goulandris Foundation. Museum of Cycladic Art. Athens.

Perlès C. 2001. The Early Neolithic in Greece: the First Farming Communities in Europe. Cambridge University Press. Cambridge.

Protsch R., Berger R. 1973. Earliest Radiocarbon Dates for Domesticated Animals. Science 179: 235-239.

Reimer P. J. and 25 co-authors. 2013. IntCal13 and Marine13 radiocarbon age calibration curves $0-50,000$ Years cal BP. Radiocarbon 55(4): 1869-1887.

Reingruber A. 2008. Die Argissa Magula: Das frühe und das beginnende Neolithikum im Lichte transägäischer Beziehungen. Die deutschen Ausgrabungen auf der Argissa Magula II. Beiträge zur ur- und frühgeschichtlichen Archäologie des Mittelmeerraums 35. Habelt. Bonn.

2015. Preceramic, Aceramic or Early Ceramic? The radiocarbon dated beginning of the Neolithic in the Aegean. Documenta Praehistorica 42: 147-158.

Reingruber A., Thissen L. 2005. ${ }^{14} \mathrm{C}$ Database for the Aegean Catchment (Eastern Greece, Southern Balkans and 
Western Turkey) 10,000 - 5500 cal BC. In C. Lichter (ed.), How Did Farming Reach Europe? International Workshop, Istanbul 2004. Byzas 2: Veröffentlichung des Deutschen Archäologischen Instituts Istanbul. Ege Yayınlarım. Istanbul: 295-327.

2009. Depending on ${ }^{14} \mathrm{C}-D a t a:$ Chronological Frameworks in the Neolithic and Chalcolithic of Southeastern Europe. Radiocarbon 51: 751-770.

2016. The 14SEA Project: $A{ }^{14} \mathrm{C}$ database for Southeast Europe and Anatolia (10,000-3000 cal BC). www.14 sea.org

Renfrew C. 1970. The Tree-Ring Calibration of Radiocarbon: An Archaeological Evaluation. Proceedings of the Prehistoric Society 36: 280-311.

Sampson A., Kozłowski J. K. and Kaczanowska M. 2003. Mesolithic Chipped Stone Industries from the Cave of Cyclope on the Island of Youra (Northern Sporades). In N. Galanidou, C. Perlès (eds.), The Greek Mesolithic Problems and Perspectives. British School at Athens Studies 10. London: 123-130.

Schier W., Draşovean F., Bayliss A. and Whittle A. 2016. Zooming into the biography of tell. High definition chronology and socialdynamics at Uivar, Romania 5200-4300 cal BC. In 23rd Neolithic Seminar Abstract Book. From Chronos to Chronologies. Department of Archaeology, Faculty of Arts, University of Ljubljana. Ljubljana: 21.

Souvatzi S. 2008. A social archaeology of households in Neolithic Greece: an anthropological approach. Cambridge University Press. Cambridge.

Stuiver M., Becker B. 1986. High-Precision decadal calibration of the Radiocarbon time scale, AD 1950-2500 BC. Radiocarbon 28: 863-910.

Theocharis D. R. (ed.) 1973. Neolithic Greece. National Bank of Greece. Athens.

Todorova H. 1995. The Neolithic, Eneolithic and Transitional Period in Bulgarian prehistory. In D. W. Bailey, I. Panayotov and St. Alexandrov (eds.), Prehistoric Bulgaria. Prehistory Press. Madison. Wis.: 79-98.

Toufexis G. 1999 (2005). Sostiki anaskaphi sti ch. th. 3220-3316 tis Anatolikis Parakampsis Larisas. Archaiologikon Deltion 54, B'1 Chronika: 424-426. (in Greek)

2000 (2009). Neolithikos oikismos sti thesi Prophitis Ilias tou D. D. Mandras, Dimos Koiladas, N. Larisas. $A r$ chaiologikon Deltion 55, B'1 Chronika: 503-505. (in Greek)
2016. Palioskala. A Late Neolithic, Final Neolithic and Early Bronze Age settlement in the Eastern Thessalian Plain (Central Greece). In Z. Tsirtsoni (ed.), The $\mathrm{Hu}$ man Face of Radiocarbon: Reassessing chronology in prehistoric Greece and Bulgaria, 5000-3000 cal BC. Travaux de la Maison de l'Orient et de la Méditerranée Série recherches archéologiques. Lyon: 361-380.

forthcoming. Habitation activity and organization of space in Late Neolithic settlements of Thessaly. Examples from the settlements Mandra (Profitis Ilas), Makrychori, Rachmani and Galini. PhD thesis. University of Thessaly. Volos.

Toufexis G., Tserga K. and Papanikolaou E. 2009. Rescue excavations at a Neolithic site near the Vasilis village, prefecture of Larisa. In Prakitika epistimonikis synantisis Volos 2009. Archaiologiko Ergo Thessalias kai Steras Elladas (AETHSE) 3: 113.

Trantalidou K. 2003. Faunal remains from the earliest strata of the Cave of Cyclope, Youra. In N. Galanidou, C. Perlès (eds.), The Greek Mesolithic. Problems and Perspectives. The British School at Athens. London: 143-172.

Tsirtsoni Z. 2016. The Human Face of Radiocarbon: Reassessing Chronology in prehistoric Greece and Bulgaria, 5000-3000 cal BC. Travaux de la Maison de l'Orient et de la Méditerranée-Série recherches archéologiques. Lyon.

Tsountas Chr. 1908. Ai proistorikai akropoleis Diminiou kai Sesklou. Bibliothiki tis en Athinais Archaiologikis etaireias. Athens. (in Greek)

Wace A. J. B., Thompson M. S. 1912. Prehistoric Thessaly. Cambridge University Press. Cambridge.

Weißhaar H.-J. 1989. Die deutschen Ausgrabungen auf der Pevkakia-Magula in Thessalien. Bd 1: Das späte Neolithikum und das Chalkolithikum. Beiträge zur ur- und frühgeschichtlichen Archäologie des Mittelmeer-Kulturraumes 28 . Habelt. Bonn.

Weninger B., Clare L., Gerritsen F., Horejs B., Krauß R., Linstädter J., Özbal R. and Rohling E. J. 2014. Neolithisation of the Aegean and Southeast Europe during the 6600-6000 cal BC period of Rapid Climate Change. Documenta Praehistorica 41: 1-31.

Wijnen M. H. J. M. N. 1981. The Early Neolithic Settlement at Sesklo: An Early Farming Community in Thessaly, Greece. Analecta Praehistorica Leidensia 14: 1-146. 